\title{
Artikel
}

\section{Projectbesluitvorming voor natte waterstaatswerken op grond van de Waterwet en de Omgevingswet}

\author{
Mr. dr. F.A.G. (Frank) Groothuijse*
}

\section{Inleiding}

Voor de aanleg of wijziging van waterstaatswerken door of vanwege de beheerder van deze waterstaatswerken zijn veelal meerdere besluiten noodzakelijk. Het gaat dan om de vaststelling van een projectplan tot de aanleg of wijziging van een waterstaatswerk zelf en in voorkomende gevallen de goedkeuring daarvan. Daarnaast zijn voor de aanleg of wijziging van waterstaatswerken veelal besluiten nodig op grond van andere omgevingsrechtelijke wet- en regelgeving, zoals de Wet ruimtelijke ordening (Wro) of de Wet algemene bepalingen omgevingsrecht (Wabo). Uiteindelijk moet de nieuwe toestand van het aangelegde of gewijzigde waterstaatswerk (normatief) worden verankerd in de legger. Niet altijd is duidelijk op welke wijze deze besluiten zich tot elkaar verhouden en hoe de rechtsbescherming daartegen is geregeld. In de jurisprudentie is een aantal onduidelijkheden weggenomen, maar de jurisprudentie heeft ook nieuwe vragen opgeroepen. Daarnaast hebben zich met inwerkingtreding van de wetswijziging van 1 juli $2014^{1}$ enkele voor de praktijk relevante wijzigingen van wet- en regelgeving voorgedaan. Hoogste tijd dus om deze ontwikkelingen op een rijtje te zetten en in het licht van zowel omgevingsrechtelijke regelgeving als de Algemene wet bestuursrecht $(\mathrm{Awb})$ te beoordelen.

* Mr. dr. F.A.G. Groothuijse is als senior onderzoeker omgevingsrecht verbonden aan het Utrecht Centre for Water, Oceans and Sustainability Law van de Universiteit Utrecht.

1. Stb. 2014, 155
Allereerst zal worden ingegaan op de legger, waarin de normatieve toestand van waterstaatswerken moet worden beschreven. De legger omschrijft waaraan een waterstaatswerk naar vorm, afmeting en constructie moet voldoen en geeft bovendien aan waar de aan een waterstaatswerk grenzende beschermingszones zijn gelegen. ${ }^{2}$ Als de beheerder van het waterstaatswerk daar wijzigingen in wil aanbrengen ten opzichte van de in de legger beschreven toestand, zal hij (in beginsel) een projectplan moeten vaststellen. Ook dit projectplan zal worden besproken, waarbij tevens zal worden ingegaan op de projectprocedure die op de aanleg en wijziging van bepaalde waterstaatswerken van toepassing is. De vraag is vervolgens hoe een projectplan, dat voorziet in de aanleg of wijziging van een waterstaatswerk ten opzichte van de legger, zich verhoudt tot de legger. Ook de relatie tot de planologische besluitvorming zal daarbij aan de orde komen. De verhouding tussen legger, projectplan en planologische besluitvorming speelt bij de aanleg en wijziging van bergingsgebieden een bijzondere rol. In een ander artikel heb ik reeds aandacht besteed aan het bergingsgebied, ${ }^{3}$ maar de jurisprudentie die sinds de introductie over deze juridische figuur is verschenen, in het bijzonder over de verhouding tussen projectplan, legger en planologische besluitvorming, geeft anleiding om daaraan enkele woorden te wijden. Tot slot zal vooruit worden geblikt op de betekenis die

Art. $5.1 \mathrm{Wtw}$

3. F.A.G. Groothuijse, Bergingsgebieden uniform geregeld in de Waterwet. De aanwijzing, aanleg, regulering en ingebruikname van bergingsgebieden onder de Waterwet, TBR 2010/158 (hierna: Groothuijse 2010a). 
de Omgevingswet ${ }^{4}$ voor de aanleg en wijziging van waterstaatswerken door of vanwege de beheerder zal hebben.

\section{De legger voor waterstaatswerken}

\subsection{Inleiding}

In het waterrecht kunnen twee typen leggers worden onderscheiden. In de eerste plaats de onderhoudslegger, waarin wordt aangegeven wie welke waterstaatswerken moet onderhouden. Deze legger wordt vastgesteld op grond van art. 78 lid 2 van de Waterschapswet (Wsw). Daarnaast kent art. 5.1 van de Waterwet (Wtw) de legger voor waterstaatswerken, waarin de beheerder van een waterstaatswerk moet vastleggen waaraan het waterstaatswerk wat betreft ligging, vorm, afmetingen en constructie moet voldoen. Een overzichtskaart waarop de ligging van waterstaatswerken en eventueel daaraan grenzende beschermingszones staat aangegeven, maakt onderdeel uit van de legger. De leggerplicht bestaat in beginsel voor alle waterstaatswerken die de beheerder in beheer heeft, tenzij voor het desbetreffende waterstaatswerk een vrijstelling is verleend. ${ }^{5}$ Bij of krachtens provinciale verordening (en voor rijkswaterstaatswerken bij of krachtens AMvB) kan de beheerder vrijstelling van de leggerplicht worden verleend voor waterstaatswerken die zich naar hun aard, functie of vanwege de geringe afmetingen niet lenen voor een omschrijving in de legger. ${ }^{6}$ De legger als bedoeld in art. $5.1 \mathrm{Wtw}$ is van belang voor de aanleg en wijziging van waterstaatswerken, zodat in deze bijdrage uitsluitend op deze legger zal worden ingegaan. ${ }^{7}$ De onderhoudslegger zal in het vervolg dan ook onbesproken blijven.

\subsection{Normatieve vastlegging begrenzing waterstaatswerken en aangrenzende beschermingszones}

De legger beschrijft in welke toestand een waterstaatswerk zou moeten verkeren en legt daarmee de normatieve toestand van een waterstaatswerk vast. Daarmee geeft de legger ook aan waar de beheergrenzen exact gelegen zijn. De legger duidt met andere woorden aan waar een waterstaatswerk begint en waar het ophoudt. De algemene bewoordingen waarmee waterstaatswerken in art. 1.1 Wtw zijn omschreven - waterkeringen, oppervlaktewaterlichamen, ondersteunende kunstwerken en ber-

4. Stb. 2016, 156. Op het moment van schrijven zijn de AMvB's en de Invoeringswet Omgevingswet nog niet ter advisering aan de Raad van State voorgelegd. De wet zal tezamen met de invoerings- en uitvoeringswetgeving op zijn vroegst in het voorjaar 2019 in werking treden.

5. Zie art. 5.1 lid 3 Wtw.

6. Het beschrijven van de toestand van de Noordzee, de Waddenzee of vrij meanderende wateren is blijkens de parlementaire geschiedenis onevenredig belastend voor de beheerder, zodat voorzien is in een vrijstellingsmogelijkheid (Kamerstukken II 2008/09, 31 858, nr. 3, p. 26-27).

7. Waar in deze bijdrage wordt gesproken over legger wordt dan ook de legger als in art. $5.1 \mathrm{Wtw}$ bedoeld. gingsgebieden - krijgen in de legger een exacte (normatieve) begrenzing. Omdat bevoegdheden en verplichtingen van de beheerder veelal gerelateerd zijn aan de bij hem in beheer zijnde waterstaatswerken, zoals de projectplanplicht voor de aanleg of wijziging van waterstaatswerken, de vergunningplicht voor het gebruik maken van een waterstaatswerk op grond van het $\mathrm{Wtb}$ of de waterschapskeur, de gedoogplichten van hoofdstuk 5 Wtw enzovoort, bepalen deze beheergrenzen tevens de reikwijdte van de bevoegdheden en beheertaken die de beheerder ten aanzien van deze waterstaatswerken heeft. De legger speelt in de jurisprudentie van de Afdeling een belangrijke rol bij de vraag of er in een concreet geval sprake is van een waterstaatswerk. Zo oordeelde de Afdeling dat voor de vraag of sprake is van een dijklichaam slechts van belang is of dit in de (water)regelgeving als zodanig is aangeduid. De Afdeling overweegt in haar uitspraak van 8 juni 2011:

'Anders dan N.A.G. betoogt, is voor de vraag of sprake is van een dijklichaam slechts van belang of deze in de regelgeving als zodanig is aangegeven. Niet van belang is of de regionale waterkering visueel bezien het profiel heeft van een dijklichaam.'

Hoewel het in deze uitspraak een aanduiding van een kering in een provinciale reglementaire verordening betrof, kan onder de door de Afdeling gehanteerde term 'regelgeving' naar mijn oordeel ook een aanduiding in de legger worden begrepen. Waar het mijns inziens om gaat, is dat de Afdeling in deze uitspraak duidelijk maakt dat niet de visuele kenmerken bepalend zijn voor de juridische kwalificatie als waterkering, maar de publiekrechtelijke aanwijzing daarvan. ${ }^{9}$ In een uitspraak van 17 december $2014^{10}$ volgt de Afdeling dezelfde lijn. De Afdeling oordeelt namelijk dat de uiterlijke verschijningsvorm geen rol speelt bij de vraag of sprake is van een (primaire) waterkering, maar dat daarvoor de in de legger beschreven toestand doorslaggevend is.

In de uitspraak van 7 november 2012 volgt de Afdeling evenwel een andere benadering. In die uitspraak stelt de Afdeling vast of in het concrete geval naar uiterlijke verschijningsvorm sprake is van een waterkering. De Afdeling overweegt:

'Uit de hiervoor genoemde bepalingen [art. 1.1 lid 1 Chw jo. cat. 7.3 bijlage I Chw; FG] volgt dat afdeling 2 van hoofdstuk 1 van de Chw van toepassing is op alle besluiten die zijn vereist voor de wijziging van een waterstaatswerk op grond van artikel 5.4, eerste lid, van de Waterwet. Ingevolge artikel 1.1, eerste lid, van de Waterwet, wordt onder een waterstaatswerk onder meer een waterkering begrepen. Gezien de

8. ABRvS 8 juni 2011, M en R 2011/188 m.nt. F.A.G. Groothuijse.

9. Zie ook ABRvS 24 december 2013, AB 2014/72 m.nt. S. Handgraaf. In deze uitspraak accepteert de Afdeling dat het waterschapsbestuur bij de feitelijke vaststelling van de ligging van een waterstaatswerk gebruik maakt van een voor eenieder kenbare (keur)kaart. Een dergelijke kaart kan volgens de Afdeling in casu dus dienen ter verduidelijking van de legger.

10. ABRvS 14 december 2014, ECLI:NL:RVS:2014:4543. 
omvang en de ligging van het dijkvak in relatie tot het daarachter liggende havengebied en land, merkt de Afdeling het dijkvak aan als een waterkering.' ${ }^{\text {,1 }}$

De Afdeling lijkt daarbij de legger niet van belang te achten voor de vraag of sprake is van een waterkering (en daarmee dus ook van een waterstaatswerk). Echter, in dezelfde uitspraak acht de Afdeling de kwalificatie van het dijkvak in de legger wel degelijk van belang voor de beantwoording van de vraag of het dijkvak als een primaire waterkering kan worden gekwalificeerd. Weliswaar stelt de Afdeling allereerst vast dat het dijkvak voor dijkring 30 is gelegen en daarmee, gelet op de definitie van het begrip 'primaire waterkering', ${ }^{12}$ enkel daardoor beveiliging biedt tegen overstroming, zodat aan deze definitie is voldaan. Het dijkvak is echter op de kaartbijlagen van I en IA niet uitdrukkelijk als primaire waterkering weergegeven, zoals art. 1.3 lid $1 \mathrm{Wtw}$ wel vereist. Desondanks is de Afdeling van oordeel dat in casu sprake is van een primaire waterkering, omdat het doel van de kaartbijlagen volgens de wetsgeschiedenis niet is om op gedetailleerd schaalniveau aan te duiden waar een primaire waterkering precies ligt of moet komen te liggen. Doel van de kaartbijlage is om globaal aan te duiden waar een gesloten stelsel van dijkringen ligt en welk veiligheidsniveau daarmee correspondeert. De legger is volgens de Afdeling wel (mede) bedoeld om exact aan te duiden waar een primaire waterkering is gelegen.

De uitspraken van 8 juni 2011 en 17 december 2014 zijn naar mijn oordeel lastig te rijmen met de uitspraak van 7 november 2012. In de laatstgenoemde uitspraak lijkt de Afdeling eerst vast te stellen of naar uiterlijke verschijningsvorm sprake is van een waterkering, om daarna aan de hand van de kaartbijlagen in combinatie met de legger te bepalen waar deze is gelegen. In de uitspraken van 8 juni 2011 en 17 december 2014 acht de Afdeling daarvoor uitsluitend de aanwijzing in de legger van belang. Vanuit het oogpunt van rechtszekerheid is de lijn die de Afdeling in beide uitspraken volgt in mijn ogen te prefereren, omdat de rechtszekerheid vereist dat buiten alle twijfel moet staan waar de geldende wet- en regelgeving voor waterstaatswerken van toepassing is. Die duidelijkheid biedt de legger.

Dat de aanwijzing op de legger bepalend is voor de ligging van een waterstaatswerk, maakt de definities van de begrippen 'waterstaatswerk' en 'waterkering' in juridisch opzicht niet betekenisloos. Bij de vaststelling van de legger zal de beheerder immers van deze definities moeten uitgaan, in die zin dat de waterstaatswerken die daarin worden opgenomen, moeten voldoen aan de definitiebepalingen van de Wtw. Daarbij heeft de beheerder weliswaar beoordelingsvrijheid, maar die kan niet zo ver gaan dat op de legger waterstaatswerken worden opgenomen die niet voldoen aan de definitiebepalingen van art. 1.1 lid $1 \mathrm{Wtw}$.

11. ABRvS 7 november 2012, ECLI:NL:RVS:2012:BY2483, M en R 2013/75 m.nt. F.A.G. Groothuijse, AB 2012/383 m.nt. Van Hall.

12. Ingevolge art. 1.1 lid $1 \mathrm{Wtw}$ wordt onder primaire waterkering verstaan een waterkering die beveiliging biedt tegen overstroming doordat deze behoort tot een dijkring ofwel vóór een dijkring is gelegen.
Zo is de aanwijzing van een vijver waarin geen ecosysteem aanwezig is en die niet in verbinding staat met andere wateren waarin wel een ecosysteem voorkomt, als oppervlaktewaterlichaam op de legger in mijn ogen in strijd met art. 1.1 lid $1 \mathrm{Wtw}$. Met het in die bepaling gedefinieerde begrip 'oppervlaktewaterlichaam' heeft de wetgever immers willen aansluiten bij jurisprudentie van de Hoge Raad en de Afdeling, die beide de aanwezigheid van een ecosysteem in een oppervlaktewaterlichaam veronderstellen. ${ }^{13}$

\subsection{Onderhoud of aanleg/wijziging van een waterstaatswerk?}

Regelmatig moet worden getoetst of waterstaatswerken aan de in de legger omschreven toestand voldoen. ${ }^{14}$ Die toestand komt niet altijd overeen met de feitelijke toestand waarin een waterstaatswerk zich bevindt. De feitelijke toestand van een waterstaatswerk kan bijvoorbeeld ten gevolge van erosie, aanlanding of begroeiing afwijken van de in de legger omschreven toestand. In dat geval zal de beheerder of een andere onderhoudsplichtige onderhouds- of herstelwerkzaamheden moeten plegen om het waterstaatswerk weer aan de in de legger gestelde eisen te laten voldoen. ${ }^{15} \mathrm{Er}$ is in dat geval geen sprake van de wijziging van een waterstaatswerk, zodat voor deze werkzaamheden geen projectplan hoeft te worden vastgesteld.

Indien de beheerder de feitelijke toestand van een waterstaatswerk wil wijzigen ten opzichte van de in de legger vastgelegde normatieve toestand, zal de beheerder daarvoor ingevolge art. 5.4 Wtw een projectplan moeten vaststellen (zie par. 3). De legger is dan ook bepalend voor de vraag of er sprake is van onderhoudsen/of herstelwerkzaamheden aan waterstaatswerken, of dat er sprake is van de aanleg of een wijziging van een waterstaatswerk, waarvoor de beheerder een projectplan moet vaststellen.

\subsection{Beperking van appellabiliteit van de legger}

De legger kan worden aangemerkt als een concretiserend besluit van algemene strekking, omdat daarin wordt bepaald waar bij of krachtens de Wtw of op grond van de keur gestelde normen en regels, zoals vergunning-, onderhouds- en gedoogplichten, van toepassing zijn. De legger bevat geen zelfstandige normstelling, maar bepaalt slechts waar de normstelling uit andere waterregelgeving van toepassing is. De legger is in zoverre op rechtsgevolg gericht en kan dan ook worden aangemerkt als een besluit in de zin van art. 1:3 lid 1 Awb, waartegen in beginsel bestuursrechtelijke rechts-

13. Kamerstukken II 2006/07, 30 818, nr. 3, p. 88, HR 30 november 1982 AB 1983/265 en ABRvS 20 november 2002, ECLI:NL:RVS: 2002:AF0836, JM 2003/32 m.nt. Lammens.

14. Art. $2.12 \mathrm{Wtw}$. De beoordeling van de waterstaatkundige toestand van primaire waterkeringen zal mede moeten geschieden aan de hand van de legger. Daarbij moeten echter ook de op grond van art. 2.3 Wtw vastgestelde faalfactoren, de veiligheidsnorm en de technische leidraden in de zin van art. 2.6 lid $1 \mathrm{Wtw}$ worden betrokken (zie art. 2.12 lid 4 Wtw).

15. Zie bijv. ABRvS 14 augustus 2013, AB 2013/336 m.nt. H.F.M.W. van Rijswick en ABRvS 12 mei 2010, AB 2010/203 m.nt. Alfred van Hall. 
bescherming openstaat. Hoewel mij geen uitspraken bekend zijn waarin de Afdeling uitdrukkelijk heeft overwogen dat er tegen de vaststelling van de legger bestuursrechtelijke rechtsbescherming openstaat, blijkt uit de jurisprudentie dat de Afdeling daar wel zonder meer van uitgaat. ${ }^{16}$ In die jurisprudentie behandelt de Afdeling de beroepsgronden die appellanten aanvoeren tegen de vaststelling van de legger immers inhoudelijk. Zou de Afdeling van oordeel zijn dat de legger geen appellabel besluit is, dan had de Afdeling de beroepsgronden in deze uitspraken ambtshalve niet-ontvankelijk moeten verklaren, aangezien de regels over de bevoegdheid van de rechter (in casu art. 8:1 jo. art. 1:3 lid 1 Awb) van openbare orde zijn, waaraan hij ambtshalve moet toetsen. In de eerder aangehaalde uitspraak van 7 november 2012 overweegt de Afdeling dat het besluit tot vaststelling van de legger onherroepelijk is, hetgeen eveneens impliceert dat de Afdeling van oordeel is dat daartegen beroep bij de bestuursrechter heeft opengestaan.

Met de wetswijziging van 1 juli $2014^{17}$ is beoogd om de rechtsbeschermingsmogelijkheden tegen de legger te beperken. De vaststelling van de legger is immers op bijlage 2 van hoofdstuk 1 Awb (negatieve lijst in de zin van art. 8:5 Awb), tenzij daarbij de ligging van een waterbergingsgebied of beschermingszone wordt vastgesteld of gewijzigd. ${ }^{18}$ Achtergrond van deze wetswijziging is dat tegen watervergunningen of projectplannen op grond waarvan is besloten tot afwijking van de in de legger omschreven toestand van het waterstaatswerk reeds rechtsbescherming heeft opengestaan. Voor zover de herziening van de legger slechts voorziet in de vastlegging van wat reeds op grond van deze besluiten is toegestaan, is de vaststelling van de legger volgens de memorie van toelichting bij het wetsvoorstel niet gericht op rechtsgevolg en dus ook geen besluit in de zin van art. 1:3 Awb.

Gaat het om wijzigingen van de legger waar geen appellabel besluit aan voorafgaat en die wel rechtsgevolg hebben, dan is de vaststelling van de legger volgens de memorie van toelichting daarentegen wel een appellabel besluit. Het gaat dan in de eerste plaats om de aanwijzing van bergingsgebieden in de legger, die samen met de planologische aanwijzing nodig is voor het in het leven roepen van een bergingsgebied (art. $1.1 \mathrm{Wtw}$ ) met de daarmee samenhangende plicht voor grondeigenaren om tijdelijke waterberging op hun gronden te dulden (art. 5.26 Wtw). ${ }^{19}$ Daarnaast blijft de legger appellabel voor zover daarin de ligging van een aan een waterstaatswerk grenzende beschermingszone wordt aange-

16. ABRvS 9 december 2009, $M$ en R 2010/26 m.nt. F.A.G. Groothuijse, ABRvS 9 oktober 2013, ECLI:NL:RVS:2013:1468, ABRvS 9 oktober 2013, ECLI:NL:RVS:2013:1461, AB 2013/395 m.nt. W.J. van DoornHoekveld en ABRvS 7 november 2012, M en R 2013/75 m.nt. FA.G. Groothuijse. Zie ook Rb. Noord-Nederland 21 mei 2013, ECLI:NL:RBNNE:2013:CA0738, waarin wel uitdrukkelijk is geoordeeld dat de legger een concretiserend besluit van algemene strekking is waartegen bestuursrechtelijke rechtsbescherming openstaat.

17. Stb. 2014, 155 .

18. Zie Kamerstukken II 2012/13, 33 503, nr. 3, p. 16

19. Zie par. 6. wezen. Binnen een beschermingszone worden ter bescherming van het waterstaatswerk handelingen zoals graven, bouwen, draineren, enzovoort gereguleerd bij vergunningplicht of algemene regels. Deze inhoudelijke normstelling geschiedt niet in de legger, maar in het Waterbesluit voor rijkswaterstaatswerken ${ }^{20}$ en in de keur voor waterstaatswerken in beheer bij het waterschap. ${ }^{21}$ De legger bepaalt dus niet welke regels binnen beschermingszones zelf gelden, maar uitsluitend waar de inhoudelijke normstelling voor handelingen in beschermingszones precies van toepassing is. Omdat beschermingszones geen onderdeel uitmaken van het waterstaatswerk zelf, kunnen deze niet door de vaststelling van een projectplan worden aangewezen of in het leven geroepen, zodat tegen de aanwijzing van beschermingszones in de legger nog geen bestuursrechtelijke rechtsbescherming heeft opengestaan.

De veronderstelling in de memorie van toelichting dat de vaststelling van een legger geen besluit zou zijn, voor zover daarin uitsluitend de toestand van een waterstaatswerk wordt vastgelegd overeenkomstig een daaraan voorafgaand in werking getreden projectplan of watervergunning, lijkt mij onjuist. Het enkele feit dat in de legger wijzigingen van waterstaatswerken worden vastgelegd, die hun grondslag hebben in een projectplan of watervergunning, makt immers nog niet dat daaraan het besluitkarakter komt te ontvallen. Een watervergunning en een projectplan hebben namelijk andere rechtsgevolgen dan de legger. ${ }^{22}$ Zowel het projectplan als de watervergunning geeft de beheerder onderscheidenlijk de vergunninghouder de juridische titel om een waterstaatswerk aan te leggen of te wijzigen. De legger daarentegen, geeft geen juridische titel voor de aanleg of wijziging van een waterstaatswerk, maar omschrijft waaraan een waterstaatswerk wat betreft vorm, afmeting en constructie moet voldoen (de normatieve toestand). Zoals reeds is betoogd in paragraaf 2.2, is deze normatieve toestand tevens bepalend voor de vraag waar een waterstaatswerk precies is gelegen en de beheertaak van de beheerder ten aanzien van het desbetreffende waterstaatswerk. De legger heeft dan ook een andere functie en andere rechtsgevolgen dan het projectplan en de watervergunning, zodat de verlening van een watervergunning of de vaststelling (of de goedkeuring) van een projectplan niet leidt tot een wijziging van de normatieve toestand van het waterstaatswerk, zoals deze is omschreven in de legger. Daarvoor is juist nog een aanpassing van de legger noodzakelijk. De vaststelling van

20. Art. 6.5 onder c Wtw jo. par. 6 van hoofdstuk 6 Wtb.

21. Wederom merk ik op dat in art. 6.5 onder c Wtw en ook in art. 6.14 Wtb ten onrechte de suggestie wordt gewekt dat een beschermingszone tot het waterstaatswerk zou behoren. Dit is in tegenspraak met de definitie van beschermingszone in art. $1.1 \mathrm{Wtw}$, waarin is vermeld dat een beschermingszone aan een waterstaatswerk grenst en daar dus per definitie geen deel van uitmaakt. Zie punt 2 van mijn noot bij ABRvS 9 december 2009, M en R 2010/26.

22. Indien op een projectplan de projectprocedure van par. 2 van hoofdstuk 5 Wtw van toepassing is, dan treedt het projectplan pas in werking als dat plan door GS is goedgekeurd. 
de legger is naar mijn oordeel dan ook een Awb-besluit, ${ }^{23}$ ook als daarin slechts de wijziging van een waterstaatswerk wordt vertaald met een grondslag in een eerder in werking getreden projectplan of watervergunning.

Voor dit standpunt kan ook steun worden gevonden in de uitspraak van de Afdeling van 9 oktober 2013, waarbij de vaststelling van een legger aan de orde is waarin de normatieve toestand van een waterstaatswerk wordt aangepast aan een eerder uitgevoerde wijziging van het waterstaatswerk, waarvoor reeds een watervergunning was verleend. Appellant voert aan dat de demping van een water niet in de legger had mogen worden opgenomen, omdat voor die demping ten onrechte een keurontheffing (watervergunning) is verleend. De Afdeling acht deze beroepsgrond blijkbaar ontvankelijk, aangezien zij deze beroepsgrond inhoudelijk behandelt. ${ }^{24}$ Zou de Afdeling van oordeel zijn dat het besluitkarakter aan de legger zou zijn komen te ontvallen door de eerder voor de demping verleende watervergunning, dan had zij de beroepsgrond ambtshalve niet-ontvankelijk moeten verklaren.

Los van de vraag of de vaststelling van bepaalde onderdelen van de legger al dan niet als besluit kwalificeert, staat de vraag of het wenselijk is dat tegen vaststelling van de legger bestuursrechtelijke rechtsbescherming openstaat, voor zover daarin slechts wijzigingen in de normatieve toestand van waterstaatswerken worden vastgelegd, die hun grondslag reeds hebben in een watervergunning of een projectplan. Dat lijkt mij onwenselijk. Belanghebbenden die bezwaren hebben tegen de wijziging van het waterstaatswerk, hadden immers tegen de watervergunning of het projectplan bestuursrechtelijke rechtsmiddelen kunnen aanwenden. Wanneer deze besluiten eenmaal onherroepelijk zijn, zal de beheerder niet anders kunnen doen dan de daaruit voortvloeiende wijzigingen van het waterstaatswerk in de legger verwerken. Het is niet efficiënt om tegen de wijziging van het waterstaatswerk over de band van de vaststelling van de legger, waarin deze wijziging wordt verwerkt, nogmaals beroep open te stellen. De uitsluiting van bestuursrechtelijke rechtsbescherming tegen de vaststelling van de legger waarin een reeds eerder vastgesteld projectplan of verleende watervergunning wordt verwerkt, is naar mijn oordeel dan ook alleszins verdedigbaar.

De ratio van de uitsluiting van bestuursrechtelijke rechtsbescherming tegen de vaststelling van de legger in gevallen waarin tegen de wijziging van een waterstaatswerk reeds in het kader van een projectplan of watervergunning beroep heeft opengestaan, zou kunnen worden vergeleken met de ratio van art. 3.10 Wro. Op grond van deze bepaling staat geen bestuursrechtelijke rechtsbescherming open tegen de vaststelling van een bestem-

23. De constatering dat de vaststelling van de legger een besluit is in de zin van de Awb, ook indien daar geen bestuursrechtelijke rechtsbescherming tegen openstaat, betekent bovendien dat hoofdstuk 3 Awb daarop van toepassing is.

24. ABRvS 9 oktober 2013, ECLI:NL:RVS:2013:1468. Zie ook ABRvS 11 januari 2012, AB 2012/37 m.nt. Alfred van Hall. mingsplan, voor zover dat plan uitsluitend een inpassing behelst van een project waarvoor eerder een omgevingsvergunning in de zin van art. 2.1 lid 1 onder c Wabo (afwijkingsvergunning) is verleend. Overigens kan in dit geval ook niet worden volgehouden dat het bestemmingsplan door de eerdere verlening van een afwijkingsvergunning niet langer op rechtsgevolg gericht is en om die reden geen besluit meer zou zijn.

Een vraag die sinds de beperking van de appellabiliteit van de vaststelling van de legger aan belang heeft gewonnen, is of reserveringszones ${ }^{25}$ onder de definitie van 'beschermingszone' van art. $1.1 \mathrm{Wtw}$ vallen. Sindsdien staat tegen de aanwijzing van reserveringszones immers slechts beroep bij de bestuursrechter open, voor zover deze reserveringszones kunnen worden aangemerkt als beschermingszone in de zin van art. 1.1 lid 1 Wtw. Volgens deze bepaling is een beschermingszone een aan een waterstaatswerk grenzende zone waarbinnen ter bescherming van het waterstaatswerk voorschriften en beperkingen kunnen ${ }^{26}$ gelden. Of zones die gericht zijn op het reserveren van aangrenzende ruimte ten behoeve van (een) toekomstige wijziging(en) van het waterstaatswerk als beschermingszones in de zin van art. 1.1 lid $1 \mathrm{Wtw}$ kunnen worden beschouwd, is bij mijn weten nog niet in de jurisprudentie beantwoord. De strekking van de wetswijziging tot beperking van de appellabiliteit van de legger pleit er echter voor om tegen de aanwijzing van reserveringszones bestuursrechtelijke rechtsbescherming mogelijk te achten. Tegen deze aanwijzing heeft immers niet eerder bestuursrechtelijke rechtsbescherming opengestaan. Dat zou pleiten voor dusdanig ruime interpretatie van het begrip beschermingszone dat reserveringszones die grenzen aan een waterstaatswerk ook onder dit begrip worden geschaard. Voor reserveringszones die niet direct aan een waterstaatswerk grenzen, kan een dergelijke ruime interpretatie echter geen soelaas bieden, omdat deze niet aangrenzend zijn aan een waterstaatswerk en dus niet onder de wettelijke definitie van het begrip beschermingszone vallen. ${ }^{27}$

25. Dat de beheerder reserveringszones kan vaststellen, is in de jurisprudentie aanvaard. Zie o.m. ABRvS 8 juni 2011, M en R 2011/188 m.nt. F.A.G. Groothuijse, ABRvS 9 juni 2010, AB 2010/211 m.nt. AvH, ABRvS 28 januari 2004, AB 2004/116 m.nt. AvH, Rb. Middelburg 29 januari 2008, AWB07/389, M en R 2008, 29K en F.A.G. Groothuijse, Water weren. Het publiekrechtelijke instrumentarium voor de aanpassing en bescherming van watersystemen ter voorkoming en beperking van wateroverlast en overstromingen (diss. Utrecht), Den Haag: IBR 2009, p. 260-265

26. Een beschermingszone waarbinnen geen voorschriften of beperkingen gelden, lijkt me niet voorstelbaar. Binnen een beschermingszone gelden per definitie voorschriften en/of beperkingen, zodat gebruik van het woord 'kunnen' in de definitie van beschermingszone mij overbodig lijkt.

27. Zie ook G.M. van den Broek, F.A.G. Groothuijse \& H.F.M.W. van Rijswick, Ruimte voor dijken. Een onderzoek naar het juridisch instrumentarium voor het reserveren van ruimte voor toekomstige dijkenversterkingen, in: Hoogheemraadschap Schieland en Krimpenerwaard, Pilot 'ruimtelijk instrumentarium dijken', p. 53-59 en 79. Zie www.uu.nl/ utrecht-centre-for-water-oceans-and-sustainability-law/adviezen. 


\section{Het projectplan}

\subsection{Inleiding}

Indien de beheerder van een (onderdeel van een) watersysteem een waterstaatswerk wil aanleggen of wijzigen, dient hij daarvoor een projectplan vast te stellen. Een projectplan dient een beschrijving van het betrokken werk en de wijze waarop dat zal worden uitgevoerd te bevatten. Ook moeten daarin de voorzieningen worden beschreven die worden getroffen om de nadelige gevolgen van de uitvoering van het werk te voorkomen of te beperken. ${ }^{28}$ Ten aanzien van de verlegging van een primaire waterkering kan het projectplan voorzieningen bevatten met betrekking tot de inpassing in de omgeving van het gebied tussen het oorspronkelijke tracé van de waterkering en het nieuwe tracé.

Zoals in paragraaf 2 reeds is opgemerkt, dient de beheerder uitsluitend een projectplan vast te stellen indien hij wenst af te wijken van de toestand zoals deze omschreven is in de legger. Voor de aanleg van een nieuw waterstaatswerk zal de beheerder dan ook een projectplan moeten vaststellen, omdat het desbetreffende waterstaatswerk voorheen niet in de legger zal zijn beschreven en er in zoverre dus sprake is van afwijking van de in de legger omschreven toestand. Dit doet de vraag rijzen of er voor de aanleg of wijziging van waterstaatswerken waarvoor ingevolge art. 5.1 lid $3 \mathrm{Wtw}$ een vrijstelling van de leggerplicht geldt, een projectplan moet worden vastgesteld. In die gevallen kan namelijk niet worden bepaald of en in hoeverre wordt afgeweken van de legger. Indien er desondanks toch een projectplan moet worden vastgesteld, is de vraag in welke gevallen dat moet gebeuren. Mogelijk is dat het geval als de beheerder wijzigingen wil aanbrengen ten opzichte van een waterstaatswerk dat door de beheerder feitelijk reeds gedurende een significante periode als zodanig is aangemerkt en onderhouden. ${ }^{29}$

\subsection{Projectprocedure}

De beheerder kan een waterstaatswerk niet aanleggen of wijzigen zonder daarvoor een projectplan vast te stellen. De vaststelling is dan ook op (publiekrechtelijk) rechtsgevolg gericht en daarmee een besluit in de zin van art. 1:3 Awb. Op de vaststelling van een regulier projectplan zijn de hoofdregels van de Awb van toepassing. ${ }^{30}$

Op projectplannen tot de aanleg of wijziging van primaire waterkeringen of andere waterstaatswerken van bovenlokale betekenis waarvan in de provinciale verordening is bepaald dat deze met spoed op gecoördineerde wijze tot stand moeten worden gebracht, is de projectprocedure van toepassing. Dat houdt in dat op de

28. Dat wil overigens niet zeggen dat alle nadelige gevolgen door maatregelen of voorzieningen in het projectplan moeten worden voorkomen. Eventueel resterend nadeel kan op grond van de nadeelcompensatieregeling van art. 7.14 Wtw voor vergoeding in aanmerking komen. Zie ABRvS 4 december 2013, AB 2014/296 m.nt. E.H.J. Plambeck.

29. Vgl. ABRvS 9 december 2009, M en R 2010/26 m.nt. F.A.G. Groothuijse, r.o. 2.8.1.

30. Bezwaar bij het waterschapsbestuur, beroep bij de rechtbank en hoger beroep tegen de rechtbankuitspraak bij de Afdeling. besluiten die nodig zijn voor de uitvoering van het projectplan de gecoördineerde voorbereidings- en rechtsbeschermingsprocedure van paragraaf 2 van hoofdstuk 5 Wtw van toepassing is. Deze besluiten worden met afdeling 3.4 Awb voorbereid en daartegen staat gelijktijdig beroep in eerste en enige aanleg open bij de Afdeling. Het projectplan waarop de projectprocedure van toepassing is, moet worden goedgekeurd door gedeputeerde staten (GS). Tevens voorziet de regeling in een plaatsvervangende beslisbevoegdheid voor GS indien uitvoeringsbesluiten door andere dan rijksorganen niet, niet tijdig of niet overeenkomstig het projectplan worden genomen. ${ }^{31}$ Naar het oordeel van de Afdeling bestaat er geen verplichting voor GS om de benodigde uitvoeringsbesluiten gecoördineerd te behandelen. GS kunnen dan ook beslissen bepaalde uitvoeringsbesluiten buiten de coördinatieregeling te houden. ${ }^{32}$

\subsection{Afstemmingsregeling inpassingsplan en projectplan}

De beheerder stelt geen projectplan vast indien de aanleg of wijziging van een waterstaatswerk geschiedt met behulp van een provinciaal inpassingsplan, rijksinpassingsplan of tracébesluit. ${ }^{33}$ Zoals ik reeds elders heb betoogd, is dit in mijn ogen geen gelukkige regeling. ${ }^{34}$ Belangrijkste bezwaar is dat het waterschapsbestuur met een beroep op een provinciaal belang in het ruimtelijke spoor de projectplanbevoegdheid kan worden ontnomen, waar het in het gunstigste geval de vergunningverlenende bevoegdheid voor terugkrijgt. Het waterschapsbestuur kan met andere woorden als functioneel bestuur met een beroep op de in de Wro nauwelijks geclausuleerde inpassingsbevoegdheid van initiatiefnemer worden 'gedegradeerd' tot vergunningverlener. Dat doet naar mijn idee afbreuk aan het beginsel van functionele decentralisatie, dat in art. 3.2 lid 1 jo. art. 2 lid $2 \mathrm{Wsw}$ is gecodificeerd. Afwijking daarvan is op grond van de laatste zinsnede van art. 2 lid 2 Wsw uitsluitend toegestaan indien functionele decentralisatie onverenigbaar is met het belang van een goede organisatie van de waterstaatkundige verzorging.

Daarnaast is het nog maar de vraag of alle waterstaatkundige en uitvoeringsaspecten die normaliter in het

31. Art. $5.11 \mathrm{lid} 1 \mathrm{Wtw}$. Dit geldt ook voor zogenaamde facilitaire besluiten (zie art. 5.11 lid $2 \mathrm{Wtw}$ ). Dit zijn besluiten die niet strekken ter uitvoering van het projectplan, maar die nodig zijn voor de realisering van de in het projectplan opgenomen maatregelen en voorzieningen, zoals een omgevingsvergunning voor het kappen van een boom of voor het plaatsen van een kraan of een omgevingsvergunning voor het afwijken van het bestemmingsplan voor een tijdelijk werkterrein

32. ABRvS 26 oktober 2016, ECLI:NL:RVS:2016:2792.

33. Art. 5.4 lid 6 Wtw.

34. Zie F.A.G. Groothuijse, De aanleg en wijziging van waterstaatswerken: provinciaal wat kan, decentraal wat resteert? Over de ineffectieve en onnodig centraliserende werking van de regeling ter voorkoming van procedurele samenloop tussen de Wro en de Waterwet, in: P.J.J. van Buuren e.a. (red.), Toonbeelden. Gedachten over provinciaal omgevingsrecht ter herinnering aan Toon de Gier, Deventer: Kluwer 2013, p. 113-128. Zie ook H.F.M.W. van Rijswick, A.A. Freriks \& W.J. van Doorn-Hoekveld, De juiste weg: projectbesluitvorming in het overstromingsrisicobeheer, in: PJ.J. van Buuren e.a. (red.), Toonbeelden. Gedachten over provinciaal omgevingsrecht ter herinnering aan Toon de Gier, Deventer: Kluwer 2013, p. 129-144. 
projectplan moeten worden opgenomen wel in een inpassingsplan kunnen worden opgenomen. Voor zover deze aspecten niet ruimtelijk relevant zijn, kunnen ze immers niet in het inpassingsplan worden geregeld ${ }^{35} \mathrm{Of}$ een kwelvijver met stenen kaden of natuurvriendelijk met riet wordt uitgevoerd, dient wel in het projectplan te worden beschreven, maar is een uitvoeringsaspect dat in de bestemmingsplanprocedure niet aan de orde kan komen. ${ }^{36}$

Bovendien wordt met deze afstemmingsregeling niet het oorspronkelijke door de wetgever beoogde doel bereikt. Doel was te voorkomen dat de coördinatieregelingen van de Wtw en de Wro tegelijkertijd op de aanleg of wijziging van een waterstaatswerk van toepassing zouden zijn. Twee verschillende coördinatieregelingen kunnen immers niet tegelijkertijd van toepassing zijn op besluiten die nodig zijn voor de uitvoering van een project. De samenloop van beide coördinatieregelingen wordt met de huidige afstemmingsregeling echter niet volledig bereikt. Indien de minister of GS voor een nationaal of provinciaal project een omgevingsvergunning verlenen ${ }^{37}$ en daarop de coördinatieregeling van de Wro van toepassing verklaren, ${ }^{38}$ wordt namelijk de toepasselijkheid van de coördinatieregeling van de Wtw niet uitgesloten, waardoor beide regelingen tegelijkertijd van toepassing zijn. De afstemmingsregeling had wat mij betreft dan ook uitsluitend moeten zien op het voorkomen van de samenloop tussen de coördinatieregelingen van de Wro en de Wtw. Behoud van de projectplanbevoegdheid hoeft niet in de weg te staan aan gecoördineerde besluitvorming over de uitvoering van een inpassingsplan indien het projectplan (inclusief de in voorkomende gevallen vereiste goedkeuring) in dergelijke gevallen als uitvoeringsbesluit meeloopt in de coördinatieregeling van de Wro. ${ }^{39}$ Daarmee kan een onnodige inbreuk op het beginsel van functionele decentralisatie worden voorkomen. Mijn conclusie is dan ook dat de huidige afstemmingsregeling niet doelmatig is en onnodig inbreuk maakt op het functionele decentralisatiebeginsel.

\subsection{Projectplan en planologische besluitvorming} Veelal is voor de aanleg en wijziging van een waterstaatswerk naast een projectplan ook een planologisch besluit nodig. In een recente uitspraak heeft de Afdeling geoordeeld dat de Wro noch de Waterwet een volgorde voorschrijft waarin het projectplan en het planologische besluit moeten worden vastgesteld. ${ }^{40}$ Daarbij is van belang dat beide besluiten van rechtskarakter verschillen. Het bestemmingsplan bevat algemeen verbindende voorschriften die met het oog op een goede ruimtelijke ordening moeten worden vastgesteld, terwijl het projectplan een beschikking is die nodig is alvorens de beheerder tot uitvoering kan overgaan, waarbij de doel-

\footnotetext{
Zie art. 3.26 respectievelijk 3.38 jo. art. 3.1 lid 1 Wro.

ABRvS 20 augustus 2014, ECLI:NL:RVS:2014:3098.

Art. 2.4 lid 2 en 3 Wabo jo. art. 3.1 onder b en 3.2 onder b Bor

Zie art. 3.33 lid 1 en 3.35 lid 1 Wro.

Vgl. ABRvS 17 oktober 2012, ECLI:NL:RVS:2012:BY0404.

Zie ABRvS 20 augustus 2014, M en R 2015/5 m.nt. F.A.G. Groothuijse.
}

stellingen van de Wtw als belangenkader gelden. Ook hetgeen in een planologisch besluit en een projectplan kan worden geregeld, verschilt. Zoals reeds in paragraaf 3.3 is opgemerkt, kunnen waterstaatkundige uitvoeringsaspecten immers in een beroep tegen een projectplan en in voorkomende gevallen het besluit tot goedkeuring wel ter discussie worden gesteld, terwijl dat in de bestemmingsplanprocedure niet mogelijk is.

Indien op het projectplan de projectprocedure van toepassing is, kan planologische toestemming ook worden verleend met behulp van een omgevingsvergunning voor het afwijken van het bestemmingsplan. ${ }^{41}$ De omgevingsvergunning kan in dat geval als uitvoeringsbesluit meelopen in de coördinatieregeling. ${ }^{42}$

\subsection{Delegatie van de projectplanbevoegdheid aan het dagelijks bestuur}

De beheerder is bevoegd om het projectplan vast te stellen. Welk orgaan dat is, kan niet uit de Wtw worden afgeleid. Art. 1.1 Wtw definieert 'beheerder' immers als het bevoegde bestuursorgaan van het openbare lichaam belast met beheer. Welk orgaan bevoegd is tot vaststelling van projectplannen zal dan ook moeten worden afgeleid uit de algemene bevoegdheidstoedeling van de Wsw. De bevoegdheid tot regeling en bestuur berust op grond van art. $77 \mathrm{Wsw}$ bij het algemeen bestuur, voor zover deze bevoegdheid niet bij of krachtens reglement, bij wet of bij AMvB aan het dagelijks bestuur of de voorzitter is opgedragen. De projectplanbevoegdheid is niet opgedragen aan andere bestuursorganen, zodat deze bevoegdheid berust bij het algemeen bestuur. Deze bevoegdheid kon tot 1 juli 2014 niet worden gedelegeerd aan het dagelijks bestuur, aangezien de Afdeling in haar uitspraak van 18 februari $2004^{43}$ ambtshalve oordeelde dat delegatie van de bevoegdheid tot vaststelling van een dijkverbeteringsplan in de zin van art. 7 Wet op de waterkering (oud) - de voorganger van het huidige projectplan - onder het delegatieverbod van art. 83 lid 2 onder g Wsw (oud) viel. Wanneer het gaat om relatief kleine waterstaatsprojecten, zoals duikers, sluisjes en kleine aanpassingen aan waterstaatswerken, is een dergelijk delegatieverbod niet wenselijk en inefficiënt. ${ }^{44}$ De wetgever heeft dat ook ingezien en heeft met de wetswijziging van 1 juli 2014 de projectplanbevoegdheid uitgesloten van het specifieke delegatieverbod van art. 83 lid 2 onder g Wsw. Deze bepaling heeft terugwerkende kracht gekregen tot het moment van inwerkingtreding van de Wtw (22 december 2009), zodat ook gedelegeerde projectplanbevoegdheden van vóór 1 juli 2014 daardoor worden gedekt. Deze opheffing van het specifieke delegatieverbod van art. 83 lid $2 \mathrm{Wsw}$ doet volgens de memorie van toelichting niets af aan het algemene (rela-

41. Art. 2.1 lid 1 onder c Wabo.

42. Zie uitgebreider Groothuijse 2009, p. 159 e.v. en F.A.G. Groothuijse, Water weren 2.0, in: A.A.J. de Gier e.a. (red.), Goed verdedigbaar. Vernieuwing van bestuursrecht en omgevingsrecht, Deventer: Kluwer 2011, p. 318-319.

43. ABRvS 18 februari 2004, JM 2004/67.

44. Zie ook de reactie van E.W. ten Heuw op het artikel van Groothuijse 2010a, p. 852, en de reactie daarop van F.A.G. Groothuijse in TBR 2010/197. 
tieve) delegatieverbod van art. 83 lid $1 \mathrm{Wsw}$. Op grond van dit eerste lid kan het algemeen bestuur aan het dagelijks bestuur zijn bevoegdheden overdragen, tenzij de aard van de bevoegdheid zich tegen overdracht verzet. Wanneer daarvan ten aanzien van de projectplanbevoegdheid al dan niet sprake is, is niet helemaal duidelijk. Daarvan kan volgens de memorie van toelichting sprake zijn als het gaat om complexe projectplannen, met name die projectplannen waarop de projectprocedure van toepassing is. ${ }^{45}$

\section{Watervergunning voor gebruikmaking van waterstaatswerken}

\subsection{Afschaffing vergunning eigen dienst}

Indien een ander dan de beheerder van een waterstaatswerk handelingen of werkzaamheden wil verrichten die een wijziging van het waterstaatswerk tot gevolg hebben, zoals bouwen op of graven in een waterstaatswerk, is daarvoor doorgaans op grond van de $\mathrm{Wtw}^{46}$ of de waterschapskeur een watervergunning vereist.

Sinds de inwerkingtreding van de Wtw is voor de aanleg of wijziging van waterstaatswerken door of in opdracht van het waterschap geen watervergunning meer nodig. Voor handelingen die door of in opdracht van het waterschap worden verricht ter vervulling van de op grond van art. 2 lid $2 \mathrm{Wsw}$ aan het waterschap opgedragen taken is namelijk geen watervergunning op grond van de keur meer vereist. ${ }^{47}$

Ook de rijksbeheerder heeft sinds de inwerkingtreding van de Wtw geen vergunning meer nodig voor het uitvoeren van onderhoud, de aanleg of wijziging van rijkswaterstaatswerken. ${ }^{48}$ De uitzondering op de watervergunningplicht voor het gebruik van rijkswaterstaatswerken geldt sinds de wijziging van het Waterbesluit per 1 juli $2012^{49}$ niet alleen voor de rijksbeheerder zelf, maar voor alle beheerders die in het kader van de uitoefening van hun beheertaak handelingen ten aanzien van rijkswaterstaatswerken ${ }^{50}$ verrichten. Indien het waterschap voor de uitvoering van onderhouds- of versterkingswerkzaamheden aan een rivierdijk in zijn beheer gebruik moet maken van het aangrenzende rijksoppervlaktewater, heeft hij daarvoor dus sinds 1 juli 2012 geen water-

45. Kamerstukken II 2012/13, 33 503, nr. 3, p. 17.

46. Zie art. 6.5 onder c jo. hoofdstuk 6 , par. $6 \mathrm{Wtb}$.

47. Zie art. 4.14 Modelkeur, te downloaden op www.uvw.nl. Een op grond van de keur benodigde toestemming wordt in de Wtw gelijkgesteld met een watervergunning (art. 6.13 jo. art. 1.1 Wtw).

48. Art. 6.5 onder c Wtw jo. art. 6.12 lid 2 onder $c$ jo. art. 6.13 lid 2 jo. art. 6.14 lid 2 Wtb.

49. Stb. 2012, 179, p. 10-11.

50. Onder waterstaatswerken worden ook 'droge waterstaatswerken' verstaan, zodat het slaan van brugpijlers in een rijksoppervlaktewaterlichaam thans vergunningvrij is. Zie Stb. 2012, 179, p. 10. Onder de Omgevingswet is het uitvoeren van onderhoud en herstel van waterstaatswerken door of vanwege de beheerder niet alleen vergunningvrij, maar geldt daarvoor evenmin de specifieke zorgplicht van art. 6.5 concept-Bal (zie art. 6.9 lid 4 jo. art. 6.1 concept-Bal). vergunning meer nodig. Deze situatie doet zich met enige regelmaat voor, omdat de grote rivieren bij het Rijk in beheer zijn en de daaraan grenzende waterkeringen doorgaans in beheer zijn bij het waterschap. ${ }^{51}$ Voor vergunningvrije activiteiten geldt echter wel de specifieke zorgplicht van art. 6.15 Wtb. De activiteiten die de beheerder verricht ter vervulling van zijn beheertaak zijn daarvan niet uitgezonderd, zodat de specifieke zorgplicht ook daarvoor geldt. ${ }^{52}$

De afschaffing van de 'vergunning eigen dienst' is in mijn ogen een goed voorbeeld van succesvolle deregulering. Hierdoor worden immers doublures in besluitvorming en rechtsbescherming voorkomen. Met het projectplan beslist de beheerder over de aanleg of wijziging van een waterstaatswerk en de uitvoering daarvan, waarbij hij alle doelstellingen van art. 2.1 Wtw dient te betrekken. Het eisen van een afzonderlijke watervergunning voor de uitvoering van dat plan heeft dan ook geen toegevoegde waarde. Het is naar mijn oordeel onnodig en ongewenst dat het waterschapsbestuur tweemaal inhoudelijk over hetzelfde project beslist en dat belanghebbenden die beslissing vervolgens in twee afzonderlijke procedures aan de bestuursrechter ter toetsing kunnen voorleggen.

In dat kader is het wel de vraag of er nog een watervergunning voor gebruikmaking van een waterstaatswerk is vereist als er een inpassingsplan wordt vastgesteld dat voorziet in de aanleg of wijziging van een waterstaatswerk. In gevallen waarin een inpassingsplan wordt vastgesteld dat voorziet in de aanleg of wijziging van een waterstaatswerk dat in beheer is bij het waterschap, is er naar mijn mening een watervergunning vereist, omdat provinciale staten en de Minister van IenM in dat geval niet handelen in de hoedanigheid van beheerder van het waterstaatswerk. De vaststelling van een inpassingsplan maakt de aanleg of wijziging van een waterstaatswerk dan ook niet vergunningvrij. Een andere conclusie zou er bovendien toe leiden dat de beheerder van het waterstaatswerk in beginsel helemaal niets meer te zeggen heeft over de aanleg of wijziging van het waterstaatswerk dat hij na verwezenlijking zal moeten beheren. ${ }^{53}$ Voor een watervergunningvereiste pleit bovendien dat, zoals eerder opgemerkt, niet ruimtelijk relevante waterstaatkundige aspecten niet in het inpassingsplan kunnen worden gereguleerd, terwijl dat in een watervergunning wel mogelijk is. Een watervergunningplicht stelt derde-

51. Zie ook Stb. 2009, 548, p. 139

52. Onder de Omgevingswet is het uitvoeren van onderhoud en herstel van waterstaatswerken door of vanwege de beheerder niet alleen vergunningvrij, maar is daarop ook niet de specifieke zorgplicht van art. 6.5 concept-Bal van toepassing (zie art. 6.9 lid 4 jo. art. 6.1 lid 1 onder a concept-Bal).

53. Als het Rijk of de provincie de coördinatieregeling van de Wro van toepassing verklaart, kunnen zij de watervergunningbevoegdheid naar zich toe trekken (art. 3.33 lid 3 en 3.35 lid 3 Wro) of de watervergunning in de plaats van het waterschapsbestuur verlenen, indien het waterschapsbestuur onvoldoende medewerking verleent aan de totstandkoming van de benodigde watervergunning (art. 3.34 en 3.36 Wro). Als een waterschapsverordening de verwezenlijking van het project onevenredig belemmert, voorziet de coördinatieregeling zelfs in de bevoegdheid om deze wegens dringende redenen buiten toepassing te laten (art. 3.33 lid 7 en 3.35 lid 8 Wro) 
belanghebbenden in staat deze waterstaatkundige aspecten bij de bestuursrechter aan de orde te stellen. Zonder watervergunningplicht zou dat niet mogelijk zijn, waardoor er voor derdebelanghebbenden een gat in de rechtsbescherming ontstaat.

\section{Verhouding tussen legger en projectplan/ watervergunning}

De verhouding tussen het projectplan en de watervergunning tot aanleg of wijziging van een waterstaatswerk enerzijds en de legger anderzijds kan problematisch zijn. Zolang de feitelijke uitvoering van de werkzaamheden op het waterstaatswerk niet overeenkomstig het (goedgekeurde) projectplan of de watervergunning is aangevangen, is het namelijk wenselijk dat de bestaande normatieve toestand van het waterstaatswerk, zoals deze is vastgelegd in de legger, blijft gelden. Pas op het moment dat de aanleg of wijziging van het waterstaatswerk overeenkomstig het projectplan of de watervergunning feitelijk is uitgevoerd, moet de legger de nieuwe normatieve toestand van het waterstaatswerk beschrijven. Een soepele overgang van de oude naar de nieuwe normatieve toestand kan op verschillende manieren worden bereikt. Ten eerste kan de aanpassing van de legger zo veel mogelijk tegelijkertijd (en in samenhang) met de vaststelling van het projectplan of de watervergunning geschieden, waarbij het besluit tot aanpassing van de legger pas in werking zou moeten treden op het moment dat het waterstaatswerk is aangelegd of gewijzigd overeenkomstig het projectplan of de watervergunning. De bekendmaking van de gewijzigde legger zou in dat geval moeten worden afgestemd op de afronding van de werkzaamheden ter uitvoering van het projectplan. Voor zover in de legger het aangelegde of gewijzigde waterstaatswerk wordt ingepast, staat tegen de wijziging van de legger geen bestuursrechtelijke rechtsbescherming open. Worden in de legger aangrenzende beschermingszones aangewezen, dan kunnen daartegen wel bestuursrechtelijke rechtsmiddelen worden aangewend. ${ }^{54}$

Lukt het niet tijdig om de legger aangepast te krijgen aan het overeenkomstig het projectplan of de watervergunning uitgevoerde waterstaatswerk, dan geeft de legger nog de oude toestand van het waterstaatswerk weer, die niet correspondeert met de nieuwe toestand waarin het waterstaatswerk na de uitvoering van het projectplan of de watervergunning verkeert. Daardoor zijn verboden, vergunningstelsels en algemene regels ter bescherming van het waterstaatswerk die in de keur of op grond van de Wtw zijn gesteld nog van toepassing op de oude in de legger beschreven situatie. Daarom is het wenselijk

54. Zoals uiteengezet in par. 2.4 staat tegen de wijziging van de legger geen bestuursrechtelijke rechtsbescherming open, voor zover deze wijziging voortvloeit uit een eerder vastgesteld projectplan of watervergunning. In zoverre staat de vaststelling van de legger op de negatieve lijst in de zin van art. 8:5 lid $1 \mathrm{Awb}$ om, zolang de legger niet aan de nieuwe situatie is aangepast, niet de legger de normatieve toestand van het waterstaatswerk te laten weergeven, maar het projectplan of de watervergunning. In de keur kan een regeling met een dergelijke strekking worden opgenomen. Art. 3.2 lid 5 van de Modelkeur 2013 van de Unie van Waterschappen ${ }^{55}$ geeft aan hoe een dergelijke regeling in de keur zou kunnen luiden:

'Voor waterstaatwerken, waarvoor het vaststellen van een legger als bedoeld in artikel 5.1 van de wet is voorgeschreven en die op grond van een projectplan of een watervergunning zijn aangelegd of gewijzigd ten opzichte van de legger, geldt, zolang vaststelling van een legger of een wijziging van de legger niet heeft plaatsgevonden, het volgende:

a. voor de verbodsbepalingen op grond van dit artikel worden de ligging, vorm, afmeting en constructie van het waterstaatwerk aangehouden, zoals aangegeven in het projectplan of de watervergunning;

b. de beschermingszone bij een waterkering bedraagt voor primaire keringen $\langle\ldots\rangle \mathrm{m}$, voor secundaire keringen $<\ldots>\mathrm{m}$ en voor regionale keringen $<\ldots$ $>\mathrm{m}$;

c. de beschermingszone bij oppervlaktewaterlichamen bedraagt voor primaire / A-wateren aan beide zijden $\langle\ldots\rangle \mathrm{m}$ en voor secundaire / B-wateren aan beide zijden $<\ldots>$ m.'

Zolang de legger nog niet aan de actuele situatie is aangepast, heeft de in het projectplan of de watervergunning beschreven toestand ingevolge deze regeling als de normatieve toestand te gelden en niet de in de legger beschreven (oude) toestand. Dit kan slechts een tijdelijke oplossing zijn, aangezien art. 5.1 lid 1 Wtw de beheerder verplicht om het aangelegde of gewijzigde waterstaatswerk uiteindelijk in de legger op te nemen. Voor de rijkswaterstaatswerken zou een vergelijkbare regeling in het $\mathrm{Wtb}$ kunnen worden opgenomen.

\section{Bergingsgebieden}

\subsection{Inleiding}

In een eerder artikel heb ik uitvoerig aandacht besteed aan het bergingsgebied in de zin van art. 1.1 lid 1 $\mathrm{Wtw},{ }^{56}$ zodat ik daarbij in deze bijdrage niet uitvoerig zal stilstaan. ${ }^{57}$ Toch verdient het bergingsgebied in deze bijdrage een afzonderlijke bespreking, omdat de Afdeling vanwege onduidelijkheden over de ter zake van bergingsgebieden te nemen besluiten en te volgen procedures bij wijze van voorlichting aan de bestuurspraktijk

55. Te raadplegen op www.uvw.nl/publicatie/modelkeur-2013.

56. Art. 1.1 lid 1 Wtw definieert een bergingsgebied als: "krachtens de Wet ruimtelijke ordening voor waterstaatkundige doeleinden bestemd gebied, niet zijnde een oppervlaktewaterlichaam of onderdeel daarvan, dat dient ter verruiming van de bergingscapaciteit van een of meer watersystemen en ook als bergingsgebied op de legger is opgenomen'.

57. Groothuijse 2010a. 
deze figuur nader heeft uitgelegd. ${ }^{58}$ De onduidelijkheid in de bestuurspraktijk waar de Afdeling naar verwijst, werd/wordt waarschijnlijk veroorzaakt door de afwijkende rol die de legger, het bestemmingsplan en het projectplan bij de aanleg of wijziging van een bergingsgebied spelen ten opzichte van de aanleg of wijziging van andere waterstaatswerken. De aanwijzing van een bergingsgebied in de legger en in een planologisch besluit zijn namelijk beide nodig om een bergingsgebied in de zin van de Wtw, en de daarmee samenhangende plicht voor rechthebbenden om daarbinnen tijdelijke waterberging te dulden, ${ }^{59}$ in het leven te roepen.

\subsection{De drie elementen van een bergingsgebied}

In de eerdergenoemde uitspraak onderscheidt de Afdeling drie juridische elementen:

1. de aanwijzing van een gebied tot bergingsgebied in de legger en in een planologisch besluit;

2. de aanleg en inrichting van het bergingsgebied, waarvoor de beheerder op grond van art. 5.4 Wtw een projectplan moet vaststellen;

3. de feitelijke ingebruikstelling van het bergingsgebied, die door de grondeigenaar van rechtswege moet worden geduld.

Dit onderscheid is van belang voor de rechtsbeschermingsprocedures tegen de besluiten die bij elk van deze drie onderdelen aan de orde zijn. De Afdeling is namelijk van oordeel dat bij de aanwijzingen in het planologische besluit en in de legger over de aanvaardbaarheid van het bergingsgebied reeds is beslist. Over nut en noodzaak van het bergingsgebied, verenigbaarheid met andere ruimtelijke functies, de omvang en de geografische ligging van het bergingsgebied ${ }^{60}$ en de aanvaardbaarheid van eventuele schadelijke gevolgen van de ingebruikname van het bergingsgebied ${ }^{61}$ is dan ook reeds bij de aanwijzing in het planologische besluit en/ of in de legger beslist. Deze aspecten kunnen bij de vaststelling van het projectplan niet meer aan de orde komen. Bij de vaststelling van het projectplan gaat het uitsluitend nog om de keuzes die de beheerder heeft gemaakt met betrekking tot de concrete inrichting van het bergingsgebied, zoals de plaatsing van in- en uitlaatwerken, de aanleg van vluchtwegen en omdijkingen van binnen het bergingsgebied gelegen bouwwerken. Uit de uitspraak van 31 oktober 2012 blijkt dat de frequentie en mate van inundatie van het bergingsgebied evenwel niet in de procedure tegen het planologische aanwijzingsbesluit aan de orde kunnen komen, maar dat deze aspecten in het projectplan worden vastgelegd en als zodanig in de procedure tegen het projectplan aan de orde kunnen komen. ${ }^{62}$

58. ABRvS 25 april 2012, AB 2012/178 m.nt. Alfred van Hall, $M$ en R 2012/106 m.nt. F.A.G. Groothuijse, TBR 2012/183 m.nt. G.J.M. de Jager. Zie ook ABRvS 25 april 2012, M en R 2012/114 m.nt. F.A.G. Groothuijse.

59. Art. $5.26 \mathrm{Wtw}$

60. ABRvS 25 april 2012, ECLI:NL:RVS:2012:BW3869, M en R 2012/114.

61. Zie ABRvS 6 november 2013, ECLI:NL:RVS:2013:1800, r.o. 5

62. Zie ABRvS 31 oktober 2012, AB 2013/135 m.nt. W.J. van Doorn-Hoekveld, r.o. 38.5
Voor de feitelijke ingebruikstelling (derde element) is geen besluitvorming van de beheerder meer nodig, aangezien de grondeigenaar de berging van water ingevolge art. 5.26 Wtw van rechtswege moet dulden. Wel kan er voor de ingebruikstelling een feitelijke handeling nodig zijn, zoals de bediening van een inlaatwerk, maar dat hoeft niet altijd het geval te zijn. Sommige bergingsgebieden zijn zodanig ontworpen dat ze bij het bereiken van een bepaald waterpeil vanzelf vollopen.

Naast deze drie juridische elementen kan naar mijn oordeel nog een vierde element worden onderscheiden: de regulering van het gebruik van het bergingsgebied met het oog op de doelmatige werking van het bergingsgebied. Daarbij kan bijvoorbeeld worden gedacht aan het beperken van bebouwingsmogelijkheden of mogelijkheden om bepaalde (kostbare) gewassen te telen. Interessante vraag is waar die regels kunnen worden gesteld: in het bestemmingsplan, de keur of in beide? Op deze vraag ga ik in deze bijdrage niet in, aangezien ik op deze vraag reeds in andere bijdragen uitgebreid ben ingegaan. De geinteresseerde lezer zij daarnaar verwezen. ${ }^{63}$

Het onderscheid tussen deze elementen is ook van belang voor de toekenning van schadevergoeding ten gevolge van de aanwijzing, inrichting of ingebruikname van een bergingsgebied en regulering van activiteiten daarbinnen. Elk van de afzonderlijke elementen kan namelijk een oorzaak voor schadevergoeding zijn, waarbij de planschaderegeling en de nadeelcompensatieregeling van art. $7.14 \mathrm{Wtw}$ beide een rol spelen. Ondanks een wettelijke voorrangsregeling kan dit procedurele complicaties met zich meebrengen. Daarop zal ik in deze bijdrage niet verder ingaan, maar verwijs ik naar een bijdrage voor het Tijdschrift voor Agrarisch Recht. ${ }^{64}$

\subsection{Zelfstandige planologische aanwijzing}

Bij de aanwijzing in het bestemmingsplan is van belang dat de gronden zelfstandig voor water(staatsdoeleinden of -berging) zijn bestemd. Een bestemming die waterberging slechts als bijbehorende voorziening toestaat, lijkt onvoldoende voor de planologische aanwijzing van een bergingsgebied, zo kan uit een uitspraak van de Afdeling van 5 november 2014 worden afgeleid. ${ }^{65}$ In die uitspraak is een bestemmingsregeling aan de orde waarin de gronden bestemd zijn voor agrarische doeleinden, waaronder bij die bestemming behorende voorzieningen voor de waterhuishouding. De Afdeling overweegt:

'De raad heeft beoogd de benodigde vervangende waterberging gedeeltelijk ter plaatse van de gronden met de bestemming "Agrarisch" te realiseren. De bestemming "Agrarisch" maakt echter slechts de rea-

63. Groothuijse 2010a. Zie ook Groothuijse 2009, p. 279 e.v., F.A.G Groothuijse, Het behoud van archeologische waarden met behulp van waterregelgevingen, TBR 2012/196, ABRvS 15 juli 2015, ECLI:NL:RVS: 2015:2254, ABRvS 28 januari 2015, AB 2015/109 m.nt. F.A.G. Groothuijse, ABRvS 11 februari 2015, AB 2015/179 m.nt. F.A.G. Groothuijse en mijn noot bij ABRvS 25 april 2012, M en R 2012/114.

64. W.J. van Doorn-Hoekveld \& F.A.G. Groothuijse, Schadevergoeding ten gevolge van bergingsgebieden: een juridisch labyrint, Agr.r. 2015, p. 358-366.

65. ABRvS 5 november 2014, ECLI:NL:RVS:2014:4003. 
lisatie van de bij deze bestemming behorende voorzieningen voor de waterhuishouding mogelijk en niet, zoals ter plaatse van de bestemmingen "Water" en "Woongebied", tevens waterlopen en waterberging onderscheidenlijk water. Het plan staat hiermee in de weg aan het realiseren van de door de raad beoogde waterberging ter plaatse van de gronden met de bestemming “Agrarisch”.'

\section{Vooruitblik: Omgevingswet en de aanleg en wijziging van waterstaatswerken}

Wat betekent de Omgevingswet ${ }^{66}$ voor de aanleg en wijziging van waterstaatswerken? Op het eerste gezicht lijkt er in grote lijnen niet zoveel te veranderen. De legger, ${ }^{67}$ het projectplan en het bergingsgebied ${ }^{68}$ zullen in de Omgevingswet in min of meer dezelfde gedaanten terugkeren. Hetgeen in het voorgaande is opgemerkt, is dan ook van betekenis voor de besluitvorming over de aanleg en wijziging van waterstaatswerken onder de Omgevingswet (hierna ook: Ow). Bij nadere bestudering is echter een aantal belangrijke wijzigingen op te merken, onder meer bij de projectbesluiten en de relatie daarvan met de gemeentelijke omgevingsplannen en de uitvoeringsbesluiten. ${ }^{69}$ Ook de appellabiliteit van de legger en de aanwijzing van beschermings- en reserveringszones in de waterschapsverordening zijn wijzigingen die juridische gevolgen kunnen hebben. In deze paragraaf zal een aantal van deze belangrijke wijzigingen nader worden belicht.

\subsection{Projectbesluit}

Het projectplan waarop de gecoördineerde projectprocedure van paragraaf $5.2 \mathrm{Wtw}$ van toepassing is, zal het projectbesluit als opvolger hebben. De inhoud van het projectbesluit en de procedure, inclusief de vereiste goedkeuring van projectbesluiten genomen door het waterschapsbestuur of door GS, komen in belangrijke mate overeen. Dat is anders als wordt gekozen voor de vaststelling van een 'integraal projectbesluit' als bedoeld in art. $5.52 \mathrm{Ow}$ dat één of meer uitvoeringsbesluiten in zich verenigt. ${ }^{70}$ Evenals thans het geval is, is de projectbesluitprocedure (inclusief de gecoördineerde voorbereiding van de door de Aanpassingswet nog aan te passen afdeling $3.5 \mathrm{Awb}$ ) van uitvoeringsbesluiten voor de

66. Stb. 2016, 156

67. Zie art. $2.39 \mathrm{Ow}$.

68. De definitie van bergingsgebied is ongewijzigd uit art. 1.1 lid 1 Wtw overgenomen in de bijlage onder A Ow. Zie voor de van rechtswege duldplicht voor tijdelijke berging van water op gronden behorend tot een bergingsgebied art. $10.3 \mathrm{lid} 4 \mathrm{Ow}$.

69. Zie in algemene zin over projectbesluiten H.A.J. Gierveld, Besluitvorming over de aanleg en wijziging van hoofdinfrastructuur. Een artikelsgewijs commentaar op de Tracéwet en de projectprocedure op grond van de Omgevingswet (1ste druk), Den Haag: IBR 2017.

70. Zie ook par. 7.3. De figuur van het integrale projectbesluit is geïnspireerd op het huidige projectuitvoeringsbesluit in de zin van afd. $6 \mathrm{Chw}$. aanleg, verlegging en versterking van primaire waterkeringen wettelijk verplicht voorgeschreven. ${ }^{71} \mathrm{Bij}$ provinciale instructieregels kan in de omgevingsverordening de projectbesluitprocedure ook op andere waterstaatswerken van toepassing worden verklaard, indien dat nodig is voor een doelmatige of doeltreffende uitoefening van taken en bevoegdheden op grond van de Omgevingswet. ${ }^{72}$ Belangrijk procedureel verschil met het huidige projectplan waarop de projectprocedure van paragraaf $5.2 \mathrm{Wtw}$ van toepassing is, is dat voorafgaand aan de vaststelling van een projectbesluit tot de aanleg of wijziging van een waterstaatswerk in beginsel de 'sneller en beter'-aanpak ${ }^{73}$ wordt gevolgd, waarbij het projectbesluit voorafgegaan wordt door een verkenningsfase, die uitmondt in een voorkeursbeslissing. ${ }^{74}$ Een andere belangrijke wijziging is dat het algemeen bestuur van het waterschap niet langer bevoegd zal zijn voor de besluitvorming over de aanleg en wijziging van waterstaatswerken, maar dat het dagelijks bestuur daarvoor in alle gevallen bevoegd gezag zal zijn.

Voor de aanleg en wijziging van waterstaatswerken, waarvoor de projectbesluitprocedure niet bij of krachtens de wet is voorgeschreven, heeft het waterschapsbestuur de bevoegdheid om een projectbesluit vast te stellen, ${ }^{75}$ maar kan het er ook voor kiezen om in plaats daarvan een omgevingsvergunning voor een wateractiviteit ${ }^{76}$ aan te vragen. ${ }^{77}$ Deze keuzevrijheid heeft het waterschapsbestuur thans niet. Het reguliere projectplan, dat thans de juridische basis biedt voor de anleg en wijziging van waterstaatswerken waarop de projectprocedure niet van toepassing is of wordt toegepast ${ }^{78}$ wordt in de Omgevingswet vervangen door de omgevingsvergunning voor een wateractiviteit. In zoverre keert de ver-

71. Art. 5.46 lid 2 jo. art. 5.46 jo. art. 16.7 Ow jo. afd. 3.5 Awb (nieuw)

72. Art. 2.23 lid 1 onder a sub 4 jo. art. 2.22 lid 1 jo. art. 2.3 lid 2 Ow. Vgl. art. 5.5 Wtw, waarbij dat alleen kan in gevallen waarin het gaat om de aanleg of wijziging van bovenlokale waterstaatswerken die met spoed en op gecoördineerde wijze tot stand moeten worden gebracht.

73. Ook wel de Elverding-aanpak genoemd.

74. Zie par. 5.2.2 Ow. Voor de aanleg en wijziging van waterstaatswerken is een voorkeursbeslissing niet verplicht gesteld, zodat ook kan worden besloten om een projectbesluit vast te stellen zonder voorafgaande voorkeursbeslissing.

75. In dat geval is de gecoördineerde voorbereidingsprocedure van afd. 3.5 Awb niet verplicht voorgeschreven.

76. Een omgevingsvergunning als bedoeld in art. 5.1 lid 2 onder $f$, sub $2^{\circ}$ Ow. Het betreft de omgevingsvergunning voor een beperkingengebiedactiviteit met betrekking tot een waterstaatswerk. Een beperkingengebied wordt in de bijlage onder A gedefinieerd als: 'bij of krachtens de wet aangewezen gebied waar vanwege de aanwezigheid van een werk of object regels gelden over activiteiten die gevolgen hebben of kunnen hebben voor dat werk of object'. Vgl. de toestemming op grond van de keur om gebruik te maken van een waterstaatswerk, die op grond van art. 6.13 Wtw wordt aangemerkt als een watervergunning in de zin van de Wtw.

77. Art. 5.44 lid 3 jo. art. 2.17 lid 1 onder a Ow. Zie ook Kamerstukken II 2013/14, 33 962, nr. 3, p. 186-187 en 511-512.

78. Art. $5.4 \mathrm{Wtw}$. In dat geval is onder het huidige recht op het projectplan de reguliere procedure van de Awb (bezwaar, beroep en hoger beroep) van toepassing, geldt geen van rechtswege gecoördineerde besluitvormings- en rechtsbeschermingsprocedure, is goedkeuring van GS niet vereist en is het algemeen bestuur bevoegd gezag met de mogelijkheid van delegatie op grond van art. 83 Wsw, tenzij de aard van de bevoegdheid zich daartegen verzet. 
gunning 'eigen dienst' dus terug onder de Omgevingswet. Het bevoegd gezag voor vergunningverlening is, evenals voor het projectbesluit, het dagelijks bestuur van het waterschap. Wanneer het waterschapsbestuur echter besluit om in de waterschapsverordening geen vergunningplicht voor de aanleg of wijziging van (bepaalde) waterstaatswerken door of vanwege de beheerder in het leven te roepen, kan een waterstaatswerk waarvoor vaststelling van een projectbesluit niet wettelijk is voorgeschreven zonder nader besluit van het waterschapsbestuur worden aangelegd of gewijzigd. In zoverre zou de rechtsbescherming tegen de aanleg of wijziging van een waterstaatswerk komen te vervallen, hetgeen een achteruitgang in rechtsbescherming zou betekenen ten opzichte van de huidige situatie. Aangezien de aanleg of wijziging van een waterstaatswerk ingrijpende gevolgen kan hebben, is dat in mijn ogen een onwenselijke situatie en ook in strijd met het uitgangspunt van de Omgevingswet dat de rechtsbeschermingsmogelijkheden van belanghebbenden niet verminderen. ${ }^{79}$ Indien er geen vergunningplicht geldt, zou het waterschapsbestuur in mijn ogen toch een projectbesluit moeten vaststellen, of zou er tegen de noodzakelijke wijziging van de legger bestuursrechtelijke rechtsbescherming open moeten staan.

\subsection{Uitwerkingsbevoegdheid projectbesluit}

Anders dan op grond van de huidige wetgeving kan het waterschapsbestuur bepalen dat het projectbesluit met inachtneming van de daarbij gestelde randvoorwaarden kan worden uitgewerkt. ${ }^{80}$ Een uitwerking volgt dezelfde procedure als het projectbesluit, ${ }^{81}$ maar op een uitwerking of wijziging is de 'sneller en beter'-aanpak van paragraaf 5.2.2 Ow niet van toepassing. ${ }^{82}$ Een aantal procedurele bepalingen die wel op het projectbesluit van toepassing zijn, is volgens mij ten onrechte niet op de uitwerking daarvan van toepassing verklaard. De uitwerking van het projectbesluit zal dus ook moeten worden goedgekeurd door GS. Waar de mogelijkheid om tegen een projectbesluit gronden aan te voeren na afloop van de beroepstermijn in art. $16.86 \mathrm{Ow}$ is uitgesloten, is dit bij een uitwerkingsbesluit niet gebeurd. Ook is de mogelijkheid om beroepsgronden aan te voeren tegen een uitvoeringsbesluit voor zover deze gronden hun grondslag hebben in een uitwerkingsbesluit niet uitgesloten, terwijl die mogelijkheid wel is uitgesloten voor zover beroepsgronden hun grondslag hebben in een projectbesluit. In het licht van de huidige jurisprudentie van de Afdeling kan worden afgevraagd of de Afdeling uitgaat van de maximale invulling van het projectbesluit inclusief uitwerking. Ook is het de vraag in hoeverre projectbesluiten waarin een uitwerkingsbevoegdheid is opgenomen, moeten worden aangemerkt als plan-

79. Kamerstukken II 2013/14, 33 962, nr. 3, p. 38.

80. Art. 5.54 Ow.

81. Art. 16.72 Ow. Evenals tegen het projectbesluit staat tegen een uitwerking in eerste en enige aanleg beroep open bij de Afdeling bestuursrechtspraak. Afgevraagd kan worden wat de toegevoegde waarde is van het opnemen van een uitwerkingsbevoegdheid in een projectbesluit. Zie daarvoor Gierveld 2017, p. 247-248.

82. Art. $5.50 \mathrm{Ow}$ m.e.r.-plichtig. Niet uitgesloten is dat het projectbesluit kan worden beschouwd als kaderstellend besluit.

\subsection{Projectbesluit als integraal besluit}

Inhoudelijk is er ook een belangrijk verschil tussen projectplan en projectbesluit. Het projectbesluit kan namelijk een integraal besluit zijn. Dat wil zeggen dat in een projectbesluit uitdrukkelijk kan worden bepaald dat het projectbesluit geldt als voor de uitvoering daarvan vereiste omgevingsvergunning of ander bij $\mathrm{AMvB}$ bepaald uitvoeringsbesluit. ${ }^{83}$ Het waterschapsbestuur kan zichtzelf dus de voor de uitvoering van een projectbesluit vereiste omgevingsvergunning(en) verlenen, waarbij het de geldende beoordelingskaders voor de desbetreffende omgevingsvergunningplichtige activiteiten moet toepassen. ${ }^{84}$ Indien een bestuursorgaan ten aanzien van de omgevingsvergunning een advies en/of instemmingsrecht heeft ten aanzien van een bepaalde activiteit, dan geldt dit recht ook ten aanzien van het projectbesluit waarmee voor deze activiteiten toestemming wordt verleend. ${ }^{85}$ Hoewel een integraal projectbesluit van het waterschapsbestuur goedkeuring behoeft van GS, gaat de bevoegdheid van het waterschapsbestuur om een integraal projectbesluit vast te stellen mijns inziens tamelijk ver. Een dergelijke bevoegdheid schuurt naar mijn oordeel met de functionele taak die aan het waterschap is opgedragen. Daar komt bij dat de goedkeuring van een integraal projectbesluit een zeer ruime reikwijdte kan hebben, omdat deze niet alleen ziet op de aanleg en wijziging van het waterstaatswerk zelf, maar ook op de uitvoeringsbesluiten die van het integrale projectbesluit onderdeel uitmaken, zoals bouw- of kaptoestemmingen. De werklast voor GS zal bij integrale projectbesluiten dan ook toenemen.

\subsection{Relatie tussen projectbesluit en omgevingsplan}

Waar het projectplan waarop de projectprocedure van toepassing is, zal opgaan in het projectbesluit, zal het bestemmingsplan opgaan in het omgevingsplan. Voor de aanleg en wijziging van waterstaatswerken waarvoor een projectbesluit zal worden vastgesteld, is onder de Omgevingswet geen afzonderlijk besluit tot wijziging of afwijking van het omgevingsplan vereist, aangezien de regels van het projectbesluit de regels van het omgevingsplan van rechtswege wijzigen, voor zover die regels met elkaar in strijd zijn. ${ }^{86}$ Een door het waterschapsbestuur vastgesteld projectbesluit kan dan ook de regels van het omgevingsplan wijzigen, voor zover die regels in strijd zijn met de regels van het projectbesluit. ${ }^{87}$ Een rechtvaardiging daarvoor is gelegen in het feit dat projectbesluiten van het waterschapsbestuur moeten worden goedgekeurd door GS, ${ }^{88}$ die daarbij ook de ruimte-

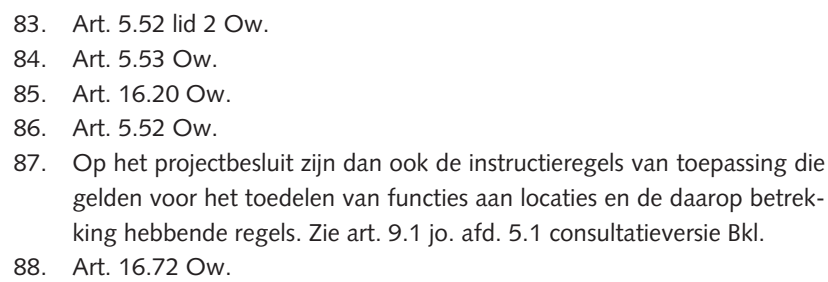


lijke aspecten moeten betrekken. Een afzonderlijke inpassing van het projectbesluit in het omgevingsplan is volgens de memorie van toelichting dan ook niet langer nodig, zodat het direct na goedkeuring kan worden uitgevoerd. ${ }^{89}$ Met dezelfde argumenten heb ik, onder meer in mijn dissertatie, ${ }^{90}$ reeds betoogd dat een gemeentelijke planologische toestemming voor de uitvoering van een door GS goedgekeurd projectplan ook in de huidige wet- en regelgeving overbodig is. GS dienen de planologische aspecten volgens vaste jurisprudentie immers reeds bij de goedkeuring van het projectplan te betrekken. ${ }^{91}$ De goedkeuring van het projectplan door GS kan naar mijn oordeel dan ook van rechtswege worden aangemerkt als een planologische toestemming ${ }^{92}$ om dat projectplan uit te voeren. Onder de Omgevingswet zou de goedkeuring van het projectbesluit dan moeten worden aangemerkt als een omgevingsvergunning voor een omgevingsplanactiviteit (in de zin van art. 5.1 lid 1 onder a $\mathrm{Ow}$ ), waarmee het omgevingsplan op grond van art. $4.17 \mathrm{Ow}$ binnen vijf jaar in overeenstemming moet worden gebracht. De gekozen regeling in de Omgevingswet gaat evenwel nog verder dan dat. Het projectbesluit zet de regels van het omgevingsplan namelijk niet slechts opzij voor zover deze aan de uitvoering van het projectbesluit in de weg staan, zoals in de door mij voorgestelde regeling, maar wijzigt deze regels automatisch. Ik waardeer de achterliggende doelstelling van deze regeling, maar naar mijn mening kan die doelstelling met een minder in de gemeentelijke omgevingsplanbevoegdheid ingrijpende regeling worden bewerkstelligd.

Deze aanpassing van rechtswege van het omgevingsplan door een projectbesluit van het waterschapsbestuur zou de aanleg van bergingsgebieden door het waterschap beduidend kunnen vereenvoudigen. Door in een projectbesluit de gronden een waterstaatkundige functie toe te bedelen wordt deze functie immers, na goedkeuring van het projectbesluit door GS, van rechtswege in het omgevingsplan verwerkt. Indien de gronden door het waterschapsbestuur ook in de legger als bergingsgebied zijn aangewezen, is er sprake van een bergingsgebied in de zin van de Omgevingswet ${ }^{93}$ en is daarop de duldplicht voor waterberging van toepassing. Een afzonderlijke gemeentelijke anwijzing van het bergingsgebied in het omgevingsplan is in dat geval niet langer nodig. Kiest het waterschap voor de aanleg van een bergingsgebied bij omgevingsvergunning, dan is een gemeentelijke

89. Kamerstukken II 2013/14, 33 962, nr. 3, p. 571.

90. Zie Groothuijse 2009, p. 159 e.v. Zie ook Groothuijse 2011, p. 321-322.

91. Zie o.m. ABRvS 15 februari 2012, ECLI:NL:RVS:2012:BV5083 en ABRvS 11 januari 2006, ECLI:NL:RVS:2006:AU9406, AB 2006/99 m.nt. A. van Hall.

92. Op grond van de huidige wetgeving zou het een omgevingsvergunning voor het afwijken van het bestemmingsplan betreffen.

93. Zie de definitie van art. 1.1 jo. bijlage onder A Ow: 'gebied waaraan op grond van deze wet een functie voor waterstaatkundige doeleinden is toegekend, niet zijnde een oppervlaktewaterlichaam of onderdeel daarvan, dat dient ter verruiming van de bergingscapaciteit van een of meer watersystemen en dat ook als bergingsgebied op de legger is opgenomen'. aanwijzing van het bergingsgebied in het omgevingsplan nog wel vereist.

In de relatie tussen projectbesluit en omgevingsplan doet zich nog een wijziging voor. Ingevolge art. 16.74 Ow kan de gemeenteraad namelijk geen omgevingsplan vaststellen, voor zover dat plan een project belemmert ten behoeve waarvan het dagelijks bestuur van het waterschap een projectbesluit heeft vastgesteld. Uit art. 16.74 lid 2 Ow kan worden afgeleid dat de uitsluiting van de omgevingsplanbevoegdheid geldt vanaf het moment van vaststelling van het projectbesluit. Tot welk moment de omgevingsplanbevoegdheid van de gemeenteraad is uitgesloten, is niet nader bepaald, zodat deze in beginsel voor onbepaalde tijd is uitgesloten. In het projectbesluit kan het waterschapsbestuur evenwel bepalen tot welk moment omgevingsplanbevoegdheid is uitgesloten. Daarna herleeft de omgevingsplanbevoegdheid van de raad.

Het waterschapsbestuur heeft evenwel niet de bevoegdheid om voorafgaand aan de vaststelling van het projectbesluit te voorzien in voorbereidingsbescherming, in die zin dat onbenutte gebruiksmogelijkheden uit het omgevingsplan die uitvoering van het projectbesluit kunnen belemmeren, kunnen worden geweerd. Indien voorbereidingsbescherming met het oog op de voorbereiding van een projectbesluit door het waterschapsbestuur gewenst is, zal het provinciebestuur door middel van het nemen van een voorbereidingsbesluit ex art. $4.16 \mathrm{Ow}$ beschermingsregels in het omgevingsplan kunnen opnemen.

\subsection{Appellabiliteit van de legger}

Een belangrijk verschil met het huidige recht is dat er in gevallen waar thans nog bestuursrechtelijke rechtsbescherming tegen de legger openstaat, dit onder de werking van de Omgevingswet niet langer het geval zal zijn. Volgens de memorie van toelichting bij de Omgevingswet zal de legger namelijk slechts een beschrijvend karakter hebben en is deze niet op rechtsgevolg gericht, omdat de aanwijzing van beperkingengebieden waarbinnen een omgevingsvergunningplicht voor waterstaatswerken geldt, niet langer in de legger, maar in de waterschapsverordening zelf onderscheidenlijk de ministeriële regeling ${ }^{94}$ plaatsvindt. Voor de vergunningplicht is de legger in zoverre inderdaad niet meer bepalend, maar zoals in paragraaf 2.4 reeds is betoogd, zal de legger wel bepalend blijven voor de begrenzing van de uitoefening van onder meer de projectbesluitbevoegdheid en de gedoogplichten. Evenals thans het geval is, zal de aanwijzing van bergingsgebieden - anders dan de memorie van toelichting bij de (consultatieversie van) Invoeringswet Omgevingswet lijkt te suggereren ${ }^{95}$ - blijkens de definitie daarvan in art. 1.1 Ow in de legger moeten blijven plaatsvinden. Aanwijzing in de legger - samen met

94. Op grond van art. 2.21a lid 1 onder b en lid 2 Ow jo. art. 2.21 lid 1 Ow.

95. Zie consultatieversie Invoeringswet Ow, MvT, p. 253 en Kamerstukken II 2013/14, 33 962, nr. 3, p. 38. 
de aanwijzing in het omgevingsplan - heeft dan ook tot gevolg dat voor het als bergingsgebied aangewezen gebied van rechtswege de duldplicht voor de tijdelijke berging van water van kracht wordt. ${ }^{96}$ De legger blijft naar mijn oordeel dan ook normatief van karakter, op rechtsgevolg gericht en een concretiserend besluit van algemene strekking. Om bestuursrechtelijke rechtsbescherming tegen de legger uit te sluiten is het dan ook noodzakelijk om deze op de negatieve lijst van bijlage 2 van hoofdstuk 1 Awb te plaatsen. Dat is ook gebeurd, ${ }^{97}$ maar door de aanwijzing van bergingsgebieden in de legger daarvan niet uit te zonderen, zoals thans wel het geval is, ${ }^{98}$ gaat de bestaande beroepsmogelijkheid tegen de aanwijzing van bergingsgebieden in de legger verloren. Voor het in het leven roepen van een bergingsgebied en de bijbehorende duldplicht zijn nu eenmaal een besluit van het gemeentebestuur (omgevingsplan) én een besluit van het waterschapsbestuur (de legger) nodig, waarbij van belang is dat de belangenkaders voor de beide besluiten verschillen. Het gemeentebestuur stelt het omgevingsplan vast met het oog op een evenwichtige toedeling van functies aan locaties, terwijl het waterschapsbestuur de legger vaststelt met het oog op de voorkoming van wateroverlast en overstromingen. Bovendien lijkt mij uitsluiting van bestuursrechtelijke rechtsbescherming tegen de aanwijzing van bergingsgebieden in de legger in strijd met het uitgangspunt van de Omgevingswet dat het (rechts)beschermingsniveau niet achteruit mag gaan. ${ }^{99}$

\subsection{Appellabiliteit aanwijzing beschermings- en reserveringszones}

Beschermings- en reserveringszones zullen niet langer worden aangewezen in de legger, maar zullen als beperkingengebied in de waterschapsverordening (voor regionale waterstaatswerken) en AMvB (rijkswaterstaatswerken $)^{100}$ moeten worden aangewezen. Hoewel daarover in het verleden nog onduidelijkheid bestond, deelt een gebiedsaanwijzing in een algemeen verbindend voorschrift volgens vaste jurisprudentie van de Afdeling bestuursrechtspraak het rechtskarakter van het algemeen verbindend voorschrift, zodat tegen die aanwijzing ingevolge art. 8:3 Awb niet langer bestuursrechtelijke rechtsbescherming meer openstaat. ${ }^{101}$ Dat geldt ook voor de in die verordening opgenomen bevoegdheid

96. Art. $10.3 \mathrm{lid} 4 \mathrm{Ow}$.

97. Zie art. 10.1 onderdeel B consultatieversie Invoeringswet Ow, waarin de legger (art. $2.39 \mathrm{Ow}$ ) in art. 1, onder Omgevingswet, onderdeel d, van bijlage 2 van de Awb op de negatieve lijst is geplaatst.

98. Zie art. 8:5 Awb jo. art. 1 onder Waterwet bijlage 2 Awb jo. art. 5.1 Wtw, behoudens voor zover daarbij de ligging van een waterbergingsgebied of beschermingszone als bedoeld in die wet wordt vastgesteld of gewijzigd.

99. Zie par. 4.2.3 van de algemene toelichting bij consultatieversie Invoeringswet Ow.

100. Zie art. 2.20 en $2.21 \mathrm{Ow}$.

101. Zie ABRvS 18 november 2015, ECLI:NL:RVS:2015:3510, JB 2016/3 en ABRvS 18 november 2015, ECLI:NL:RVS:2015:3514, JB 2016/4. Zie ook F.A.G. Groothuijse \& J. Kevelam, Handboek legger oppervlaktewaterlichamen, UCWOSL 2016, in opdracht van Waterschap De Dommel, te raadplegen op www.uu.nl/utrecht-centre-for-water-oceans-andsustainability-law/adviezen. tot wijziging van die gebiedsaanwijzing door het waterschapsbestuur. ${ }^{102}$ De Afdeling overweegt in deze uitspraak in algemene bewoordingen:

'Indien in een verordening een gebied is aangewezen waar een bepaald verbod of gebod geldt, is die aanwijzing een algemeen verbindend voorschrift. Dit geldt ook indien de verordening aan het orgaan dat de verordening heeft vastgesteld de bevoegdheid toekent de gebiedsaanwijzing die bij de verordening heeft plaatsgevonden, te wijzigen. Indien aan een ander orgaan dan het orgaan dat de verordening heeft vastgesteld de bevoegdheid is toegekend de gebiedsaanwijzing die bij de verordening heeft plaatsgevonden te wijzigen, is de wijziging door dat orgaan eveneens een algemeen verbindend voorschrift.

Indien niet in de verordening zelf een gebied is aangewezen waar een verbod of gebod geldt, maar is bepaald dat aanwijzing geschiedt bij nader besluit van het orgaan dat de verordening heeft vastgesteld of van een ander orgaan, is die aanwijzing een concretiserend besluit van algemene strekking. Het verbod of gebod dat in de verordening is neergelegd, is de normstelling. Begrenzingen in het aanwijzingsbesluit zijn geen normen of aanvullende normen en maken niet dat het aanwijzingsbesluit een algemeen verbindend voorschrift is.'

Bedacht moet worden dat de gebiedsaanwijzing, evenals andere algemeen verbindende voorschriften uit de waterschapsverordening, exceptief door de rechter kan worden getoetst bij de beoordeling van besluiten die zijn gebaseerd op de waterschapsverordening en waartegen wel bestuursrechtelijke rechtsbescherming openstaat, zoals beslissingen op aanvragen omgevingsvergunningen voor een wateractiviteit of handhavingsbesluiten. ${ }^{103}$ Exceptieve toetsing houdt in dat in een procedure bij de bestuursrechter door een belanghebbende de onverbindendheid van de onderliggende algemene regel wordt ingeroepen, of dat de rechter door een belanghebbende wordt gevraagd om het algemeen verbindend voorschrift voor het concrete geval buiten toepassing te verklaren wegens strijd met (hogere) regelgeving of een algemeen rechtsbeginsel.

Hetgeen in de memorie van toelichting en in de nota naar aanleiding van het nader verslag over rechtsbescherming tegen de legger wordt opgemerkt, is mijns inziens met elkaar in tegenspraak. In de memorie van toelichting wordt opgemerkt dat er vanwege het beschrijvende karakter tegen de legger geen bestuursrechtelijke rechtsbescherming open zal staan, terwijl in de nota naar aanleiding van het nader verslag wordt gesteld dat voor de legger zal worden aangesloten bij de thans bestaande mogelijkheden voor rechtsbescherming. $\mathrm{Nu}$ de aanwijzing van beschermingszones in de vorm

102. Zie bijv. ABRvS 18 november 2015, ECLI:NL:RVS:2015:3510, JB 2016/3 en ABRvS 18 november 2015, ECLI:NL:RVS:2015:3514, JB 2016/4.

103. ABRvS 18 november 2015, ECLI:NL:RVS:2015:3514, JB 2016/4. 
van beperkingengebieden in de waterschapsverordening het rechtskarakter van die verordening, gelet op de bovenvermelde jurisprudentie, zal delen, zal daartegen niet langer bestuursrechtelijke rechtsbescherming openstaan, zodat de bestaande rechtsbeschermingsmogelijkheden - anders dan gesuggereerd in de nota naar aanleiding van het nader verslag - niet gehandhaafd zullen worden. De opmerking in de memorie van toelichting bij de (consultatieversie van de) Invoeringswet Omgevingswet dat dit niet eenduidig uit de jurisprudentie is af te leiden, ${ }^{104} \mathrm{kan}$ ik, gelet op de duidelijke bewoordingen van de Afdeling in de hierboven aangehaalde uitspraak, dan ook niet plaatsen. Aangezien alle regels van het waterschap over de fysieke leefomgeving in de waterschapsverordening moeten worden samengebracht, ${ }^{105}$ zullen beperkingengebieden niet bij afzonderlijke besluiten kunnen worden vastgesteld, zodat daartegen ook geen bestuursrechtelijke rechtsbescherming zal openstaan. Wel kan de aanwijzing van beperkingengebieden in een waterschapsverordening worden gedelegeerd aan het dagelijks bestuur, maar dit betreft de wijziging van een algemeen verbindend voorschrift, zodat daartegen geen bestuursrechtelijke rechtsbescherming zal openstaan. ${ }^{106}$

Op rijksniveau worden beperkingengebieden begrensd bij ministeriële regeling. Begrenzing vindt dan niet plaats in de wet zelf, maar in een nader besluit door de minister in een ministeriële regeling. Gelet op de eerder aangehaalde jurisprudentie zou deze aanwijzing dus wel een concretiserend besluit van algemene strekking kunnen zijn, als daarbij wordt afgeweken van de standaardafstanden die bij AMvB voor beperkingengebieden zijn bepaald. In dat geval heeft de afwijkende begrenzing 'nieuwe' rechtsgevolgen, zodat tegen een dergelijke aanwijzing wel bestuursrechtelijke rechtsbescherming openstaat. ${ }^{107}$

\subsection{Samenloop projectprocedures}

De problematische samenloop van het projectbesluit van het waterschap en het inpassingsplan (zie par. 3.3) zal na het van kracht worden van de Omgevingswet tot het verleden behoren, aangezien deze figuren als zodanig

104. Consultatieversie Invoeringswet Ow, MvT, p. 56-57.

105. Zie Kamerstukken II 2013/14, 33 962, nr. 3, p. 94, 423 en 441

106. Zie art. $2.8 \mathrm{Ow}$.

107. Ook in de MvT bij de consultatieversie van de Invoeringswet Ow wordt dit onderkend (p. 252). niet terugkeren in de Omgevingswet. ${ }^{108}$ Wel behouden provincie en Rijk de projectbesluitbevoegdheid voor de aanleg en wijziging van projecten van provinciaal respectievelijk nationaal belang. In de (consultatieversie van de) Invoeringswet Omgevingswet is de verhouding tussen het projectbesluit van het waterschapsbestuur en de projectbesluiten van provincie en Rijk geregeld. Voor zover de aanleg of wijziging van een waterstaatswerk deel uitmaakt van een project waarvoor een provinciaal projectbesluit of rijksprojectbesluit wordt genomen, is het provinciebestuur onderscheidenlijk de Minister van IenM het bevoegd gezag. ${ }^{109}$

\subsection{Regels ter bescherming van waterstaatswerken}

De Wsw en de daarin opgenomen regelgevende bevoegdheid van het waterschapsbestuur zullen niet worden geintegreerd in de Omgevingswet. Het bestemmingsplan zal opgaan in het omgevingsplan, dat een ruimere reikwijdte zal krijgen dan het bestemmingsplan. In een omgevingsplan kunnen immers regels met betrekking tot de gehele fysieke leefomgeving worden opgenomen en niet alleen ten behoeve van 'een goede ruimtelijke ordening'. De waterschapsverordening, waarvan de grondslag de Wsw blijft, ${ }^{110}$ wordt evenwel niet geintegreerd in het omgevingsplan, maar blijft afzonderlijk daarvan bestaan. In de waterschapsverordening kunnen waterschapsbesturen het gebruik van waterstaatswerken op dezelfde wijze en met hetzelfde oogmerk (blijven) reguleren als zij thans doen. De verhouding tussen de waterschapsverordening en het omgevingsplan zal naar mijn mening dan ook niet verschillen met de huidige verhouding tussen keur en bestemmingsplan. ${ }^{111}$

108. Wel blijft het voor het Rijk (art. 4.3 jo. art. 2.3 lid 3 Ow) en de provincie (art. 4.1 lid 1 en 3 jo. art. 4.2 lid 2 jo. art. 2.3 lid 2 Ow) mogelijk om ter behartiging van nationale onderscheidenlijk provinciale belangen die niet doeltreffend en doelmatig door het gemeentebestuur kunnen worden behartigd, regels te stellen over de toedeling van functies aan locaties, al heeft doorwerking van het nationale en provinciale beleid in het omgevingsplan door middel van instructie(regels) de voorkeur. Voor provinciale omgevingsverordeningen is dit uitdrukkelijk wettelijk verankerd met betrekking tot de toedeling van functies aan locaties en met het oog daarop te stellen regels. Dit is namelijk uitsluitend mogelijk indien het provinciale belang niet doelmatig en doeltreffend met een provinciale instructieregel of instructie kan worden behartigd (art. 4.2 lid $2 \mathrm{Ow}$ ). Het omgevingsplan kan met betrekking tot de toedeling van functies aan locaties en met het oog daarop te stellen regels aldus worden overruled door een provinciale omgevingsverordening of een AMvB. In zekere zin is dit een strenger geclausuleerde opvolger van het inpassingplan, met dien verstande dat tegen de functietoedeling en met het oog daarop gestelde regels in provinciale verordeningen en AMvB's geen bestuursrechtelijke rechtsbescherming openstaat.

109. Zie art. 5.44 lid 5 en 6 Ow. Zie NvT bij consultatieversie Ow, p. 109

110. Art. 56 en 78 lid 1 Wsw.

111. Zie over de huidige relatie tussen bestemmingsplan en keur ABRvS 11 februari 2015, ECLI:NL:RVS:2015:328, AB 2015/179 m.nt. F.A.G. Groothuijse. Zie meer principieel over deze relatie Groothuijse 2009, p. 279-295. 


\section{Slot}

Zoals onder meer uit deze bijdrage kan worden opgemaakt, blijft het waterrecht in beweging. Dat geldt niet alleen voor het recht met betrekking tot de aanleg en wijziging van waterstaatswerken, dat in deze bijdrage centraal staat, maar voor het waterrecht in den brede. Dat neemt niet weg dat de huidige besluitvorming over de aanleg en wijziging van waterstaatswerken onder de Omgevingswet niet wezenlijk zal wijzigen. De legger, het projectplan, de watervergunning, de waterschapsverordening en het bergingsgebied zullen in min of meer dezelfde vorm terugkeren. Wel zal er met name ten aanzien van de beschermingszones en de projectprocedure voor de aanleg en wijziging van waterstaatswerken een aantal belangrijke wijzigingen optreden. Beschermingszones zullen in de waterschapsverordening zelf moeten worden aangewezen, waardoor daartegen niet langer bestuursrechtelijke rechtsbescherming zal openstaan. Ten aanzien van de projectbesluitvorming springt in het oog dat het waterschapsbestuur met het vaststellen van een projectbesluit, onder voorbehoud van goedkeuring van GS, het omgevingsplan direct wijzigt. Kiest het waterschapsbestuur voor de vaststelling van een integraal projectbesluit, dan kan het zelfs zelfstandig alle benodigde uitvoeringsbesluiten nemen. In mijn ogen grijpen deze bevoegdheden van het waterschapsbestuur verder in de bevoegdheden van de omgevingsplanwetgever en de oorspronkelijk bevoegde organen dan nodig is voor uitoefening van zijn actieve beheertaak.

De Omgevingswet neemt onduidelijkheden en knelpunten weg, zoals de ongelukkige antisamenloopregeling voor projectplannen en inpassingsplannen, en de in mijn ogen onnodige toestemming van de gemeente voor de aanleg en wijziging van waterstaatswerken komt te vervallen. Verder kan er geen onduidelijkheid meer bestaan over de bevoegdheid van het waterschapsbestuur om te besluiten tot de aanleg of wijziging van een waterstaatswerk; dat is in alle gevallen namelijk het dagelijks bestuur, of dat nu met behulp van een projectbesluit of een omgevingsvergunning gebeurt. Tegelijkertijd roept deze wet nieuwe vragen, onduidelijkheden en knelpunten op, waarvan ik er in deze bijdrage een aantal heb benoemd. Onduidelijk is bijvoorbeeld of het de bedoeling is om beroep tegen de aanwijzing van beschermingszones uit te sluiten of tot welk moment de omgevingsplanbevoegdheid is uitgesloten na vaststelling van een projectbesluit als daarover niets is bepaald. Potentieel knelpunt is ook de directe doorwerking van een door GS goedgekeurd projectbesluit van het waterschapsbestuur in het omgevingsplan. Ik verwacht daar uitvoeringsproblemen.

Voordat de Omgevingswet in werking treedt, zal er nog wel wat water door de Rijn moeten stromen. Dat biedt ruimte voor de nodige anpassingen.

Wordt dus ongetwijfeld vervolgd! 